\title{
CONFORMITY WITH INTERNATIONAL RECOMMENDATIONS ON MERGER REVIEWS: AN ECONOMIC PERSPECTIVE ON "SOFT LAW"1
}

\author{
Simon J. Evenett ${ }^{2}$ \\ University of St. Gallen and CEPR
}

\begin{abstract}
Alexander Hijzen ${ }^{3}$
The Leverhulme Centre for Research on Globalisation and Economic Policy, University of Nottingham
\end{abstract}

20 February 2006

\begin{abstract}
:
During the current phase of international market integration one important form of corporate restructuring is through cross-border merger or acquisition. Even though such restructuring typically affects the markets of more than one economy, almost all reviews of mergers and acquisitions consider only intra-jurisdictional effects. A prominent international initiative, that has the support of many of the world's competition authorities, seeks to foster both convergence in national merger review regimes and the voluntary adoption of international best practices. Using publicly-available survey data on these regimes, we estimate the relative importance of numerous potential legal, institutional, economic, and political-economy determinants of the degree of national conformity with four merger-related Recommended Practices of the International Competition Network (ICN). We find that the determinants of such conformity differ markedly between the founding members of the ICN and other members. Moreover, certain economic and political-economy factors appear to play a more important role in determining the degree of conformity than legal and institutional factors; a finding that has implications for both the speed and the ultimate extent of convergence in national merger regimes that can be expected from this nonbinding or soft law initiative.
\end{abstract}

\footnotetext{
${ }^{1}$ We thank Oliver Budzinski for providing very helpful comments and suggestions and the participants in the CEPR Conference on "Competition Policy for International Development, Growth and Trade" held on 9-10 December 2005 in Brussels. Financial support from the Leverhulme Trust (Programme Grant F114-BF) is gratefully acknowledged.

${ }^{2}$ Address: Simon J. Evenett, Department of Economics, SIAW--HSG, University of St. Gallen, Bodanstrasse 8, 9000 St. Gallen, Switzerland. Email: simon.evenett@unisg.ch. For other contact information see www.evenett.com.

${ }^{3}$ Address: Alexander Hijzen, Leverhulme Centre for Research on Globalisation and Economic Policy (GEP), School of Economics, Sir Clive Granger Building, University of Nottingham, University Park, Nottingham NG7 2RD, United Kingdom. Email: alexander.hijzen@nottingham.ac.uk. Telephone: +44 (0) 1158466447.
} 


\section{Introduction.}

As the impediments to many forms of international commerce have fallen firms often face greater pressure to restructure their commercial operations and have more options available to them should they do so. This restructuring has often taken the form of cross-border mergers and acquisitions whose total value approached a trillion U.S. dollars at the peak of the last wave of corporate consolidation. Despite the fact that the effects of such consolidation need not be confined to within one nation's borders, with one important exception the review of mergers and acquisitions by competition authorities remains essentially a national affair.

The goal of this paper is to examine some important consequences of the divergent approaches taken to assessing mergers and acquisitions in a globalising economy by firms, whose decisions take account of the combined effects of any planned restructuring in many jurisdictions, and by competition agencies whose decisions, by and large, do not. Legal practitioners and public officials are aware of this divergence, and a related goal of this paper will be to examine one prominent international initiative that is, in part, a response to this. More generally, this paper seeks to better understand the factors influencing international collective action on merger enforcement, drawing on both the conceptual analyses of economists as well as on the experience with implementing a significant non-binding initiative on merger reviews.

This paper is organised as follows. The insights from existing theoretical analyses of mergers and acquisitions whose effects spill over national borders are described in section two. ${ }^{4}$ Given the current system of decentralised merger enforcement, we then summarise the findings of economic research on the impact of multi-jurisdictional merger review, identifying the circumstances where the latter leads resources to be allocated in a sub-optimal manner. The developments in two leading fora, where merger enforcement matters are discussed, are described in section four, and this provides some indication of the extent to which cross-border spillovers and the potential concerns about decentralised merger reviews have been taken on board in recent years by competition agencies.

The development of Recommended Practices on the design and operation of merger review regimes has been one prominent activity of the International Competition Network (ICN), whose members are competition authorities, and in section five we assess the conformity of 56 ICN members with four of these Recommended Practices. Drawing on the extant legal, economic, and international relations literatures we propose 12 hypotheses concerning the determinants of conformity, and then confront these hypotheses with data. We discuss which hypotheses are rejected by the data and the implications of those hypotheses that are not. Concluding remarks, including a discussion of the potential significance of this paper's findings, appropriate caveats, and the areas for further research, are presented in section six.

\footnotetext{
${ }^{4}$ It is worth noting that cross-border mergers and acquisitions can be defined on the basis of their effects or in terms of the nationality of their owners. The United Nations' World Investment Report (2002), an often-used and annually-updated source of data on this subject, employs an ownership-based definition of cross-border M\&A which requires the headquarters of the merging firms to be located in two or more countries. (Of course, there is a presumption in the latter definition that the headquarters of the firm and the owners of the firm are located in the same nation.) In economic analyses of mergers, however, it is more appropriate to employ an effects-based definition according to which cross-border M\&A may be defined as M\&A between firms which operate in markets that are not confined to a single nation.
} 


\section{The welfare effects of cross-border mergers.}

In this section we review the theoretical literature on the welfare effects of cross-border mergers, focusing on the often-analysed case of an oligopoly where a homogeneous good is supplied by firms who compete in a Cournot fashion. ${ }^{5}$ Much of the existing literature takes the decision to merge as exogenous and analyses its welfare impact, rather than studying the welfare properties of endogenously-arising mergers. It turns out that, for exogenous mergers, the welfare analyses of domestic and cross-border mergers are not fundamentally different. However, this is not necessarily the case for endogenously-arising mergers. Here we review briefly both strands of the literature.

In a closed economy setting economic models of the effects of (horizontal) mergers often find that they reduce welfare. While this is the case when firms share identical unit cost functions, clear cut findings on the impact of mergers on welfare are harder to come by in the presence of marginal cost differences, fixed costs, and economies of scale. ${ }^{6}$

Farrell and Shapiro (1990, FS henceforth) show that if the objective of antitrust policy is to maximise consumer welfare then "rather impressive synergies - learning, or economies of scale - are typically necessary for a merger to reduce price" (p. 114). However, should the goal of antitrust policy be to maximise aggregate welfare, including that of consumers and producers, a more lenient stance towards mergers may be optimal.

When assessing the impact of a merger on aggregate welfare, initially it is useful to focus on the external effect of a merger, which consists of the sum of the change in the consumer surplus and the change in the producer surplus of the non-merging firms. ${ }^{8}$ FS (1990) show that in an industry with $H$ firms where $I$ of which wish to merge, the resulting merger yields a positive external effect so long as:

$$
\sum_{i \in H-I} \lambda_{i} s_{i}>s_{I} \text { and } \lambda_{i}>0
$$

where $s_{I}$ refers to pre-merger market share of the $I$ merging firms, $s_{i}$ is the pre-market share of non-merging firm $i$, and $\lambda_{i}$ is closely related to the slope of the reaction function of firm $i$, $\partial q_{i} / \partial Q_{-i}=-\lambda_{i} /\left(1+\lambda_{i}\right)$. With a linear demand function and constant marginal costs, $\lambda_{i}=1$ and a merger will have a positive external effect if the combined pre-merger market share of the merging firms, $s_{I}$, is less than $50 \%{ }^{9}$ In this case, the degree of concentration among the non-merging firms is irrelevant. ${ }^{10}$

\footnotetext{
${ }^{5}$ Demand functions for output are assumed to be linear and technology is characterised by constant, but not necessarily equal, marginal costs, unless specified otherwise.

${ }^{6}$ The effects of a merger are to be distinguished from whether a merger is actually profitable for the parties concerned, see Salant et al. (1983).

${ }^{8}$ Given that mergers are only proposed when they are expected to be profitable a sufficient condition for approving a merger is for the external effect to be positive. The external effect is easier to calculate than the impact on aggregate welfare as it allows one to treat the change in output of the merging firms as exogenous and therefore does not require an estimate of the efficiency gain of the proposed merger. In the context of cross-border mergers focusing on the external effect also avoids the need for information on the distribution of profits of the merging firms across countries.

${ }^{9}$ Such a merger may still be profitable when cost-savings due to fixed cost rationalisation and marginal cost differences are large enough (Salant et al., 1983).

${ }^{10}$ In more general cases the magnitude of external effect depends on the responses of non-merging firms and their market shares.
} 
In an open economy a merger may generate external effects at home and abroad. It can be shown that the impact of a merger on home aggregate welfare depends in part on the sectoral trade balance (Dixit, 1984; Barros and Cabral, 1994). ${ }^{11}$ Barros and Cabral (1994) show that in an open economy setting the domestic external effect of a merger between domestic firms is positive if:

$\sum_{i \in H-I} \lambda_{i} s_{i}+\left(s_{H}-d_{H}\right)>s_{I}$

where $s_{H}$ refers to the pre-merger market share of the merging firms in home and foreign markets taken together and $d_{H}$ to the share of home consumers' demand (total purchases) in the those two markets.

Condition (2) differs from the corresponding condition under autarky because of the introduction of a price and a quantity effect. The former is given by $\left(s_{H}-d_{H}\right)$, which captures the effect of a merger on the equilibrium price, decreasing as it does consumer surplus and increasing firm profits. If the home country is a net exporter (importer) of the homogeneous good, $s_{H}>(<) d_{H}$, this will increase (reduce) the domestic external effect of the merger. The quantity effect, which refers to the output responses of competing domestic firms to the merger, is always positive as $\lambda_{i}>0$.

In recent years a number of models have been developed that analyse the incentive to merge in an international oligopoly. Horn and Persson (2001) observe that while market structures that arise endogenously with only domestic mergers are never socially optimal, the welfare effects of cross-border mergers cannot be so straightforwardly characterised. The welfare effects of cross-border mergers are found to depend on the form of inter-firm rivalry in markets open to trade and foreign investment (Horn and Persson, 2001, Lommerud et al., 2005), on the inter-relationships between investment through M\&A and in greenfield sites (Norback and Persson, 2004; Bjorvatn, 2004; Ferrett, 2005), and on the impact of cross-border mergers on the costs of non-merging firms (Lommerud et al., 2005).

Horn and Persson (2001) outline a model of domestic and cross-border mergers in an international oligopoly. The model is characterised by two stages. In the first stage the industry structure is determined through decisions to merge on the part of firms. In the second stage firms decide in a Cournot fashion how much output to supply to each market. Due to the presence of trade costs exporting firms are assumed to face a marginal cost disadvantage relative to firms that only supply domestic markets. In this model trade costs have two different effects. While high trade costs create incentives for cross-border mergers along the lines of the traditional 'tariff-jumping' argument, the anti-competitive effect of trade barriers also strengthens the motivation of local firms to merge, bidding up the acquisition price. As a result cross-border mergers may be more common when trade costs are lower. Bjorvatn (2004) and Norback and Persson (2004) extend this model to allow firms to choose between greenfield investments and acquisitions as alternative modes of foreign entry. The main find-

\footnotetext{
${ }^{11}$ Dixit (1984) analyses the role of merger policy through exogenous changes in the number of domestic firms $(n)$ on welfare in an oligopolistic model of international trade. Starting from a large number of firms a reduction in $n$ initially enhances welfare, but will hurt domestic welfare for small $n$. Intuitively, merging firms provide a 'public' service to competing firms by cutting back their output. As long as the home market is large enough in terms of $n$ so that it is a net exporter of the homogenous good 'free-rider' profits accrue disproportionately to domestic firms. For low $n$ foreign firms will have a relatively large market in the domestic market. A further increase in market concentration will disproportionately benefit foreign firms while domestic consumers suffer.

${ }^{13}$ It would be interesting to see whether these results can be generalised in a multi-country setting where a firm can in principle supply many nations' markets from the same location.
} 
ings of these latter models, however, are similar to those presented in Horn and Persson $(2001)^{13}$

In contrast to standard analyses, where the effects of mergers on prices and outputs are considered, Lommerud et al. (2005) provide an example where cross-border mergers affect the marginal costs of merging and competing firms. The intuition underlying this example is as follows. Cross-border mergers increase the production locations available to newly-created multinationals. This raises these firms bargaining position relative to trade unions, resulting in lower worker compensation and so reducing the marginal costs of all the firms in the same industry.

Neary (2004) analyses cross-border mergers in an oligopoly embedded in a general equilibrium framework. Cross-border mergers are driven by the presence of technology differences across countries and therefore serve as 'instruments of comparative advantage'. The welfare effects of mergers in general equilibrium are ambiguous. In this framework only the welfare of consumers matter: "if there are benefits from more efficient resource allocation they show up not in higher profits but in lower prices throughout the economy" (p. 27).

In sum, then, theoretical analyses of mergers and acquisitions in open economies have established the different ways in which resource allocation at home and abroad is affected by this form of corporate restructuring. The sectoral balance of trade as well as impediments to international trade, such as transportation costs and tariffs, were found to influence the magnitude of these cross-border spillovers (and therefore who gains and loses from such mergers and acquisitions) and the incentive to merge in the first place.

Recognition of the actual (as opposed to theoretical) importance of cross-border effects had led more competition agencies to review transactions involving firms headquartered abroad. This, in turn, raises the question as to what the overall effect on resource allocation is of the simultaneous and independent review of mergers and acquisitions by multiple jurisdictions. We now summarise the key insights from theoretical analyses of multi-jurisdictional merger review.

\section{The effects on resource allocation of decentralised multi-jurisdictional merger review.}

Drawing on the extant economic literature in this section we discuss the implications of theoretical analyses of the current system of decentralised merger review for resource allocation, comparing the associated outcomes to the market outcomes that maximise global welfare. ${ }^{14}$ Deviations from the global optimum can take the form of either type I or type II errors. A type I error is said to occur when a merger that is blocked by a national authority would have raised global welfare. Conversely, a type II error occurs when a merger that should be banned from a global welfare perspective is, in fact, approved. ${ }^{15}$

Three assumptions, only two of which are usually made explicit, underlie theoretical analyses of decentralised merger reviews. The first assumption concerns the welfare metric adopted by national competition authority. The second assumption concerns whether the national competition authority asserts jurisdiction over mergers taking place outside its national boundaries, leading to the distinction in the literature between 'territorial' and 'extra-territorial' merger regimes. Under a territorial regime a competition authority is said to have jurisdiction only

\footnotetext{
${ }^{14}$ Given space constraints we will not address the important but distinct literature on the linkages between trade policy and competition policy see, amongst others, Dixit (1994), Levinsohn (1993), Neven and Seabright (1997), Falvey (1998), Horn and Levinsohn (2001), and Saggi and Yildiz (2006).

15 Therefore, from the point of view of world welfare, decentralised decision-making can be too strict (when type I errors occur) or too lax (when type II errors occur.)
} 
over those mergers that involve at least one domestic firm. In an extra-territorial regime a competition agency can exercise of jurisdiction over mergers irrespective of the location of the firms involved. Moreover, a competition authority is said to be acting according to the 'effects doctrine' (Neven and Röller, 2000a), when it reserves the right to scrutinise, block, or seek amendments to mergers and acquisitions that have an effect on the commerce in its jurisdiction no matter where the firms concerned are located. Application of the effects doctrine by competition agencies is one reason why a proposed merger (or acquisition) can be reviewed in multiple jurisdictions.

The third assumption is that each merger or acquisition is assessed only on the circumstances of the transaction in question and other factors are not taken into account. Therefore, tradeoffs across mergers (each of which could have different effects on a given jurisdiction) or other forms of cross-border compensation are ruled out. The absence of a transfer mechanism is one of the key features that differentiates merger review regimes from international trade negotiations. In the latter, even though a particular international obligation may reduce a nation's welfare that nation may well accept this obligation as part of a package which bundles together enough obligations so that, overall, the effect of the package is welfare-improving. The question arises as to whether the absence of such bundling or compensation in multijurisdictional merger reviews prevents resource allocation from attaining the global optimum.

Even though many competition authorities claim that their ultimate objective is to maximise consumer welfare, the academic literature has overwhelmingly assumed that authorities employ a welfare metric based on the sum of consumer and producer surplus. This discrepancy may reflect either the widespread practice of economists of analysing welfare-related matters using national welfare criteria, the more limited trade-offs involved once it is assumed that merger reviews are based on consumer welfare standards, or the perception that competition agencies actually pursue national welfare standards rather than stated consumer welfare standard.

One feature of decentralised decision-making is that the possibility arises of divergent determinations being made about the same merger by different national competition agencies. A number of papers have analysed what is known as the "scope for conflict" in merger review. Neven and Röller (2000a) present an interesting analysis of this phenomenon in a setting where competition authorities employ consumer welfare standards under regimes of extraterritorial merger review. Conflict does not arise from the presence of cross-border knock-on effects identified above but, more subtly, from the subjective definition of the relevant market. They show that conflicting decisions may arise when national merger authorities define the relevant geographical market too narrowly. Neven and Röller (2000a) also note that the fact that conflicts tend to arise in industries with global markets, where the likelihood of defining the relevant market too narrowly is small, "must then be associated with the pursuit of objectives that antitrust authorities are not supposed to pursue (...). Conflict across jurisdictions may be essentially a matter arsing from the political economy of implementation and not from external effects" (page 853).

While it is certainly possible that alternative models based on, for example, informational problems in the analysis of merger review, may better account for conflicting decisions, the possibility that antitrust officials are susceptible to capture by private interest groups cannot also be excluded. Moreover, in the public choice literature it is standard to attribute government failures to the self-interested behaviour of officials rather than to their imperfect ability 
to pursue the public interest. (Proponents of the latter approach would also treat with scepticism claims by competition authorities that they employ consumer welfare standards.)

Barros and Cabral (1994) analyse decision-making under a regime of territorial merger review based on the national welfare criterion (NWC). A price-increasing domestic merger in a netexporting industry will generate a negative effect on welfare in the foreign country for a sufficiently large positive trade balance. Given adherence to a NWC, however, the home nation's competition authority will not take any effects on foreign consumers and producers into account. Consequently, the authority at home may well approve a merger that both decreases world welfare and improves home welfare. The latter decision would generate a type II error. Now consider the case of a domestic merger that results in higher prices in an industry which initially has a negative balance of trade. The home authorities would, on the assumptions stated above, not take into account the positive cross-border spillover experienced abroad. Consequently, a potentially world welfare-improving transaction might be blocked, generating a type I error.

Head and Ries (1997) analyse the circumstances under which privately profitable but globally inefficient cross-border mergers are allowed (type II errors) under a territorial regime. ${ }^{18}$ They concentrate on two parameters: a country's share in world consumption and the extent of costsavings brought about by the merger. They show that, for a merger-to-monopoly that raises price, an increase in the cost-saving parameter raises the critical share of world consumption a country that exercises jurisdiction must have for it to commit a type II error. In other words, under a territorial regime type II errors are committed by smaller jurisdictions when evaluating mergers or acquisitions which have the prospect of generating modest cost savings.

Under a regime of extra-territorial merger review the circumstances under which type I and type II errors occur differ markedly from under territorial regimes (Falvey, 1998; Tay and Willman, 2004). In these models mergers that are approved in one country but are blocked in another country will not proceed irrespective of the nationality of the firms involved in the merger. When a merger is subject to review in all of the jurisdictions whose markets affected by the proposed transaction, a merger that reduces world welfare will never be allowed, that is, a type II error will not occur. In contrast, for a wide distribution of welfare effects across jurisdictions type I errors will result. Hence, under extra-territorial regimes the focus has tended to be on type I errors rather than type II errors. ${ }^{19}$

Some scholars have compared the effects on resource allocation of different welfare standards, comparing outcomes under a NWC with those under a consumer welfare criterion (CWC). It can be shown in a two-country setting with extra-territorial merger control that both countries are better off in terms of aggregate consumer and producer welfare under the NWC standard, so long as any conflicting decisions do not generate additional costs. ${ }^{20}$

When competition agencies base their merger reviews on a NWC standard, global welfare can be improved through two types of international cooperation, namely, through pooling sover-

\footnotetext{
${ }^{18}$ Head and Ries (1997) focus solely on type II errors "as it seems more plausible to imagine the world agency blocking mergers rather than forcing national governments to approve mergers" (p. 1111).

19 Tay and Willman (2005) show that in an asymmetric regime, where small countries cannot exercise jurisdiction extra-territoriality but large countries can, the latter prefer extra-territoriality to the operation of a supranational authority. This research identifies one potential obstacle to establishing a supranational merger authority in practice even if such an authority could in principle improve the worldwide allocation of resources.

${ }^{20}$ Neven and Röller (2000b) analyse the role of lobbying under different welfare standards. Assuming that consumers cannot lobby, in their model lobbying by firms under a CWC will tend to increase aggregate welfare by reducing the circumstances under which a type I errors results. With the assumption of a NWC lobbying will expand the set of parameters under which type II errors occur. One implication of this analysis is that improvements in the transparency of merger reviews, which here reduces lobbying, need not improve resource allocation.
} 
eignty and the creation of a supranational authority to review mergers or through "crossborder cooperation" across national merger authorities (see Text Box 1). With respect to the latter Cabral (2005) analyses, in the context of a repeated merger policy game, to what extent the 'shadow of the future' can overcome the resource misallocation created by one-shot prisoner dilemma-driven enforcement decisions. He shows that a unique trigger strategy Nash equilibrium exists in which a country is prepared to approve a merger that increases worldwide welfare even though it reduces national welfare.

Cabral focuses on finding a cooperative equilibrium that reduces type I errors. Even with repeated interaction type I errors still occur when the negative cross-border spillover experienced by a country exceeds the cost of the punishment (imposed by other countries) after deviating from the cooperative strategy. In this model, for sufficiently low discount rates all type I errors are removed. If the shadow of the future, however, does not weigh sufficiently on competition authorities--that is, if they are sufficiently short-sighted ${ }^{21}$--they may be more likely to act extra-territorially according to the effects doctrine to maximise national welfare. Cabral also shows that the possibility of remedies through asset sales further increases the range of approved mergers. Cabral's analysis is significant as it demonstrates the assumptions required for one form of decentralised decision-making on mergers to deliver the global optimum in resource allocation.

It would be fair to say that, to date, the theoretical literature on multi-jurisdictional merger regimes has better characterised the sources of inefficiency that such regimes can generate than identifying the implicit or explicit cooperation mechanisms which could improve the allocation of resources. Perhaps the significance of this literature is that merger review regimes characterised by national/own welfare maximisation, the simultaneous assertion of jurisdiction, and case-specificity, are from the perspective of optimally allocating global resources inherently sub-optimal. In which case, the preservation of national sovereignty in merger reviews comes at a price. The latter argument could, of course, be made with a lot more force if future empirical research estimated how large the price being paid by the world economy is and where (or on whom) the losses are falling most heavily.

\section{Text Box 1: Decentralised versus Centralised Merger Review.}

Figure 1 plots the net trade position of the home country, $d_{H}-s_{H}$, against the combined premerger market share of the merging firms, $s_{I}{ }^{22}$ The downward-sloping line represents the combinations for which the external effect of a merger is zero, $\Delta E_{H}=0$. Below $\Delta E_{H}=0$ the external effect is positive and above it is negative. The $\Delta E_{H}=0$-line is derived directly from equation (2). Exactly the same logic applies in the foreign country and is reflected in the $\Delta E_{F}=0$ line. The $\Delta E_{W}=0$ line represents the combinations of $s_{I}$ and $d_{H}-s_{H}$ for which the external effect of a merger on the home and foreign economy together is welfare neutral. The global welfare condition is independent of the pattern of trade between countries. A global merger authority would approve all mergers below this horizontal line. ${ }^{23}$

In a territorial merger review regime all mergers in region III will be rejected and all mergers in region VI will be approved by both countries. In regions I and II domestic mergers will be

\footnotetext{
${ }^{21}$ In the game-theoretic sense.

${ }^{22}$ The graphical analysis in Figure 1 is a straightforward generalisation of Barros and Cabral (1994) and incorporates elements from Falvey (1998), Head and Ries (1997), and Tay and Willman (2005), while remaining within the theoretical framework introduced in the previous section.

${ }^{23}$ The $\Delta E_{H}=0$-line and the $\Delta E_{W}=0$-line intersect at $\left(-\sum_{i \in F-I} \lambda_{i} s_{i}, \sum_{i \in H-I} \lambda_{i} s_{i}\right)$. This is to the left of the vertical axis
} because of the failure of national merger authorities to take account of the quantity effect of mergers on competing foreign firms. 
approved by the home country resulting in type two errors in region II, whilst domestic mergers in regions IV and $\mathrm{V}$ will be blocked resulting in type one errors in region V. Conversely, foreign mergers in region IV and $\mathrm{V}$ will be approved by the foreign country causing type two errors in region IV, while foreign mergers will be blocked by the foreign country in regions I and II resulting in type one errors in region I. It can be seen that merger review will be too lax with respect to "large" mergers in the exporting industry and too strict for "small" mergers in the import-competing industry.

Under a regime of extra-territorial merger review the circumstances under which type one and type two errors occur are different. All global welfare-reducing mergers (above $\Delta E_{W}=0$ ) are blocked as they harm the interests of at least one country. Thus, type two errors are completely eliminated. In the region below $\Delta E_{W}=0$ but to the left or right of both national welfare conditions mergers (regions I and V) global welfare-enhancing mergers are blocked by one of the national merger control bodies (type one errors). In region VI mergers are approved by both jurisdictions. Tay and Willman (2005) show that the extra-territorial regime yields lower welfare to both countries than the territorial regime.

[Insert Figure 1 here]

\section{Prominent international initiatives on merger enforcement and related matters.}

Even though leading competition practitioners are well aware that cross-border spillovers can be created by mergers and acquisitions (see, for example, ICPAC 2000, Muris 2001), outside of the European Union there has been a strong reluctance to pool sovereignty on mergerrelated matters and to create supranational enforcement bodies. Typically, the preference of legal practitioners and public officials in competition agencies has been to foster cooperation between competition agencies, to share experiences on enforcement matters in international fora, to strengthen competition agencies in developing countries and transition economies through technical assistance, and to encourage the adoption of best practices in merger reviews by competition agencies. To the extent that these initiatives have been spelt out in international accords, such accords have tended to be non-binding and their implementation voluntary. In this section we describe two fora where important international initiatives on merger-related matters have taken place. ${ }^{24}$

The members and secretariat of the Organisation for Economic Co-operation and Development (OECD) have had a long-standing interest in the international consequences of merger reviews and the steps necessary to foster cooperation between competition agencies. In 1960 the OECD's Council adopted a Recommendation concerning cooperation between its members on anti-competitive practices that affected international trade. This Recommendation suggested that OECD members should co-ordinate their investigations of cases of mutual concern, which could include investigations into proposed mergers and acquisitions. The sharing of information, under appropriate circumstances, was also encouraged. Subsequently, the OECD's Competition Committee has been a particularly active forum for the exchange of national enforcement experience and for discussions on the notification of mergers that involve commerce in more than one jurisdiction.

\footnotetext{
${ }^{24}$ It is worth noting that discussions on competition law and policy have taken place in other international fora, including the United Nations Conference on Trade and Development and the World Trade Organization. The emphasis in this section on the activities of the Organisation for Economic Co-operation and Development and the International Competition Network reflects the fact that the members of these two international bodies have been particularly active in discussing national merger enforcement matters and in devising international initiatives on merger reviews.
} 
In recent years, the OECD's Competition Committee and Trade Committee have, through their Joint Group on Trade and Competition, examined (amongst other matters) the implications of certain cross-border mergers and acquisitions and the respective merits of different means of fostering cooperation between competition agencies. Finally, in 2005 the OECD's Council adopted another Recommendation, this time on merger review. This Recommendation, which is non-binding, encourages member governments and competition agencies to cooperate, where appropriate, in their investigations of mergers and to explore international initiatives that could reduce or eliminate impediments to cooperation and coordination.

Even though the OECD has organised a number of Global Forums on competition policy, to which public officials and experts from many countries are invited, the OECD's membership is confined to the industrialised countries. Moreover, the inter-governmental and tripartite nature of the OECD implies that competition enforcement officials join in discussions on competition matters at the OECD with other government officials and with the representatives of trade unions, the business community, and the consumer movement. One does not have to take a stand on the value of such diverse groups' contributions to discussions on competition law and policy to make the point that, until recently, some competition agencies did not feel that they had their own international forum. This was to change with the creation of the International Competition Network (ICN) in October 2001.

Fourteen jurisdictions, led by the United States and European Union, founded the ICN, which has been described as "the only international body devoted exclusively to competition issues" (ICN 2005a, page 2). ${ }^{25}$ The members of the ICN are competition authorities (or other public bodies responsible for the implementation of competition laws), not states or governments. Since its foundation the competition authorities of another 76 jurisdictions have joined the ICN, making it effectively worldwide in membership. According to ICN (2005a), there were two reasons why the ICN was created. The first reason was the recognition that economic interdependence meant that a growing number of competition law-related investigations had cross-border components and could involve more than one competition authority. This raised the risk of different authorities reaching divergent conclusions about the same commercial matter. The second reason stated is, with the spread of competition law around the globe ${ }^{26}$, "it was felt that there was a need for an organisation specialised in competition, and organised by and for competition agencies themselves" (ICN 2005a, page 2). Some have argued that the ICN was created to forestall potential developments in other fora, in particular the signing of binding obligations on competition law and policy at the World Trade Organization (see Bode and Budzinski, 2005). ${ }^{27}$

The Mergers Working Group has been one of the most active components of the ICN since its inception. ${ }^{28}$ This Group seeks "to promote movement toward best practices in the design and operation of merger review systems" (ICN 2005a, page 3) and has undertaken a series of projects to this end, of which the development of a set of eight Guiding Principles and 13 Recommended Practices for merger notification and review procedures is a leading example. ${ }^{29}$ These Principles and Practices have been adopted by the ICN's membership and adherence to

\footnotetext{
${ }^{25}$ More information about the ICN can be found at www.internationalcompetitionnetwork.org

${ }^{26}$ Over one hundred jurisdictions are said to have enacted some form of competition legislation.

${ }^{27}$ In this respect it is instructive to note the following remark in ICN (2005a): "It is important to stress that the ICN does not seek any "top down" harmonisation of competition law and policies throughout the world. It not only lacks the competence to do so, but more fundamentally takes the view that any attempt at wholesale harmonisation would do injustice to the great diversity of the economic, institutional, legal and cultural settings prevalent in the home jurisdictions of its member agencies" (page 2).

${ }^{28}$ For two assessments of the ICN's activities see Kraus and Coppola (2004) and Budzinski (2004).

${ }^{29}$ The rationale for devising these Principles and Practices is said to be three-fold: to enhance the effectiveness of national merger enforcement, to reduce the burdens (both public and private) of multi-jurisdictional merger control, and to facilitate convergence in approaches to merger review (ICN 2005a, page 4).
} 
them is voluntary. Like most of the ICN's Working Groups, the Mergers Working Group has been assisted by so-called non-governmental advisers, including private practitioners, former officials, academics, and other interested parties. However, only competition agencies make decisions within the ICN, employing the principle of consensus in Working Group meetings, in the ICN's Steering Group (which is made up of a subset of the ICN's membership), and at the ICN's Annual Conferences.

The two initiatives described above have certainly increased the communication between many competition agencies. It is quite likely that cooperation between competition agencies has also been encouraged by these initiatives, however there are other mechanisms (including bilateral agreements between competition agencies) that foster cooperation too. Determining precisely how much case-specific cooperation between competition agencies takes place, and what its effects are, is particularly difficult given the paucity of verifiable information on these matters. Competition officials assert routinely that informal cooperation happens and is effective, while others have expressed their doubts as to the scale and impact of such cooperation (see, for example, Ryan 2005 and Jenny 2003 for different perspectives on this matter.) Fostering cooperation is, however, only one of the objectives of recent international initiatives on competition law and policy. Promoting the adoption of best practices, in particular in the area of merger review, has been one of the prominent objectives of the ICN and now we turn to an empirical assessment of the degree of conformity with four of the ICN's Recommended Practices and the factors which appear to influence such conformity.

\section{Estimating the determinants of conformity with a prominent international soft law initiative on merger review.}

In this section we estimate the determinants of the degree of conformity by competition agencies in 56 jurisdictions with four important Recommended Practices that were unanimously adopted by the members of the International Competition Network (ICN). ${ }^{30}$ In doing so we will evaluate 12 hypotheses concerning the degree of conformity. This evaluation could reveal which, if any, legal and institutional changes tend to enhance conformity with the ICN's Recommended Practices. Moreover, we could learn if the degree of conformity tends to be constrained by slow-changing variables, such as the level of national income, or by relatively entrenched political factors. We will make use of a detailed survey of conformity commissioned by a group of leading international companies and economic consultancies that was undertaken in 2004 by several internationally-recognised members of the private bar. The next subsection describes that survey in more detail.

\subsection{The Merger Streamlining Group's survey on the implementation of four ICN Recommended Practices.}

The private competition bar has played a prominent role in assessing the implementation of the very ICN Recommended Practices that it advised competition agencies on drafting and adopting. In particular, a team of internationally renowned competition law practitioners ${ }^{31}$

\footnotetext{
${ }^{30}$ As will become clear, these four Recommended Practices refer specifically to procedural and institutional matters associated with a merger review and not to the analytical techniques that might be employed by a competition agency during a merger review. It is logically possible, therefore, for a competition agency to adhere to international best practices on procedural matters while failing miserably in its economic analysis of mergers. This implies that it would be erroneous to assume that implementing best practices on procedural and institutional matters necessarily results in an improved allocation of resources. Moreover, it is an open empirical question as the extent to which the former results in the latter.

${ }^{31}$ This team included Janet McDavid, Phillip Proger, Michael Reynolds, J. William Rowley, and A. Neil Campbell.
} 
conducted two distinct surveys on the implementation of the ICN's Recommended Practices in 2003 and in 2004 at the request of the Merger Streamlining Group. ${ }^{32}$ The survey conducted in 2003 assessed "compliance ${ }^{33 "}$ with the first three ICN Recommended Practices (on the jurisdictional nexus of merger reviews, notification thresholds of merger reviews, and matters relating to the timing of notification to competition agencies of proposed or completed mergers or acquisitions.) This was followed by a much more extensive survey of the degree of implementation of the next four Recommended Practices adopted by the ICN, those relating to the important matters of the length of time for a merger to be reviewed, the requirements for initially notifying a transaction to the authorities, the transparency of merger review procedures, rules, guidelines, and decisions, and the review of merger control provisions. ${ }^{34}$

Rowley and Campbell (2005, page 3) note that the 2003 and 2004 "surveys were designed to gather information that is as objective as possible in order to allow an assessment of the level of implementation of each Recommended Practice in each ICN jurisdiction." The 2004 survey comprised 34 questions, all but four ${ }^{35}$ of which addressed a different aspect of the second batch of Recommended Practices adopted by the ICN or the extensive commentaries on each of these Practices that have been published by the ICN's Mergers Working Group. ${ }^{36}$ It is worth noting that not every aspect of the four Recommended Practices were the subject of a question in the 2004 survey. Moreover, the majority of questions referred to the advice given by the ICN's Mergers Working Group concerning these four Recommended Practices, rather than to the text of the Recommended Practices themselves. (It may also be worth noting here that typically the former are considerably more specific than the latter.)

The survey questionnaire was initially devised by the above-mentioned team of private practitioners and then sent to two senior members of the ICN for comment. The revised questionnaire was sent in late February and early March 2004 to the heads of the 74 competition agencies that were members of the ICN at that time, with a request that the survey be returned in four weeks or less (the significance of this request will become clear in the text that follows.) The same revised questionnaire was also sent to one local legal counsel or academic with expertise in competition law in each jurisdiction that was an ICN member at the time.

Rowley and Campbell (2004) report that 33 competition agencies returned "substantially complete" surveys by 7 April 2004; the cut-off date for inclusion in their preliminary report.

\footnotetext{
${ }^{32}$ The members of this Group are Alcan Inc., British Telecom, Charles River Associates, Compaq Computer Corporation, General Electric Company, Goldman Sachs International, NERA, Rio Tinto PLC, and Vodafone Group PLC.

${ }^{33}$ While many readers may find the term compliance, as it relates to such international norms, neutral, it is worth noting that many competition officials that we spoke to balked at this term, often preferring to use the term "conformity." The latter term also appears in ICN documentation on the Recommended Practices see, for example, page 2 of ICN (2005b). To some the term compliance implies that there may be an obligation to adhere to the ICN's Recommended Practices, whereas it has been argued that their implementation is voluntary. Competition officials may also fear that if their agency is not perceived to be in compliance then they will come under pressure from the private sector bar and others to take steps, some of which may encroach on their discretion, authority, and prerogatives, to come into compliance. While some readers may regard these matters as merely semantic, those who follow the evolution of the ICN will recognise just how sensitive these matters are, especially to officials serving in actual or nominally independent competition agencies. Another point to bear in mind is that the degree of implementation and degree of conformity are often used synonymously in the literature on the ICN. To the extent that full implementation leads to complete conformity then there is some logic to this.

${ }^{34}$ These four Recommended Practices are often referred to as "Review Periods," "Requirements for Initial Notification," "Transparency," and "Review of Merger Control Provisions." Originally these four Recommended Practices were numbered IV through VII, respectively. In 2004 Practice number VI (Transparency) was renumbered VIII and Practice number VII (Review of Merger Control Provisions) was renumbered IX.

${ }^{35}$ The 2004 survey included four questions about the implementation of ICN recommendations in general. As the answers to these questions did not relate to the implementation of a specific Recommended Practice, we did not use this data in the empirical analysis conducted for this paper.

${ }^{36}$ Appendices A-B of Rowley and Campbell (2004) reproduce the questionnaire used in the 2004 survey.
} 
No competition agency explicitly declined to participate, but 38 failed to respond to the questionnaire. Legal counsel and academic scholars returned 43 substantially complete surveys. Again none of the latter openly declined to respond but 28 sent in no response. Rowley and Campbell (2004) note that "the slightly higher private sector response rate may reflect resource availability... and/or possible self-selection biases. Agencies which are not committed to implementation of Recommended Practices may have been less inclined to respond, while private law firms were presumably not subject to the same disincentive and may have welcomed the opportunity for visible participation in the public policy process" (footnote 15, italics in the original text). Another possibility is that private law firms may have been reluctant to publicly ${ }^{37}$ evaluate an agency that it has dealings with, especially if a truthful evaluation showed a low level of implementation of the ICN's Recommended Practices. This phenomenon may be more important in jurisdictions with smaller competition law communities (where it may be the case that everyone knows what everyone else is up to.) In this regard it is worth noting that, with the exceptions of France, Japan, and Mexico, every other jurisdiction where there was no private sector response had a relatively small population.

Appendix C of Rowley and Campbell (2004) identifies the 60 jurisdictions where at least one survey response was received in time for inclusion in their preliminary report. ${ }^{38}$ Of the 60 jurisdictions for which some form of response was received by 7 April 2004, the coded survey responses for only 56 of them are reported in Appendices D-G of Rowley and Campbell (2004). ${ }^{39}$ Moreover, of the 30 questions relating specifically to the implementation of the four ICN Recommended Practices, 25 coded responses were reported in Appendices D-G. The primary data source for our study, then, includes these coded responses for each of the 56 jurisdictions, yielding a maximum of 1400 possible observations on national merger regimes.

A survey response was coded zero if there was no implementation of a particular ICN Recommended Practice, aspect of a particular Recommended Practice, or associated commentary on a given Recommended Practice. Following the original survey, partial implementation (as assessed by the survey respondent) was coded 0.5 and full implementation was coded 1.0. Separate codes were used to indicate where no response was given and when the response "not applicable" was reported. ${ }^{40}$ Rowley and Campbell (2004) note that, in those jurisdictions where a response was received from a competition agency and a private sector expert, any disagreements in their reported responses tended to be resolved in favour of the competition agency (page 10 footnote 17). Unfortunately, Rowley and Campbell (2004) do not report, where they exist, the separate responses of a competition agency and a private sector expert from the same jurisdiction, but they note that these responses were "generally congruent" (page 10).

In addition to concerns about the potential subjectivity in answering survey questions, in coding errors, and the like, we wanted to check whether the 56 jurisdictions for which responses were available were representative of the ICN's total membership of 74 jurisdictions (at the time the survey was completed.) In particular we are interested in the following questions: were the survey responses skewed towards richer countries, towards agencies that were inde-

\footnotetext{
37 The identities of all the private sector survey respondents are listed in Appendix C of Rowley and Campbell (2004). The possibility of anonymous private sector responses does not appear to have been considered by the organisers of this survey.

${ }^{38}$ In a subsequent paper these authors reported that responses from five more ICN jurisdictions were received, see page 2 of Rowley and Campbell (2005). These latter survey responses have not been made publicly available and thus are not part of our analysis. Moreover, as far as we can discern no final report has been subsequently published on the internet or elsewhere.

${ }^{39}$ We could find no explanation for this discrepancy.

${ }^{40}$ Of the total of 1400 possible responses 121 of them, amounting to less than ten percent, were coded "no response" or "not applicable" and so were dropped from our empirical analysis. The total number of observations in our sample, therefore, was 1279.
} 
pendent, towards jurisdictions that receive more foreign direct investment (of which crossborder mergers and acquisitions is a component), or towards locales where more foreign lawyers are based? In addition, were responses more likely from those jurisdictions whose competition agencies were initial members of the ICN? Likewise, were responses more likely from those jurisdictions whose competition agencies served on the ICN Mergers Working Group at the time of the survey? Or was the likelihood of a response determined by the fact that a jurisdiction had a merger review law in the first place, bearing in mind that not all ICN members have such a law on their statute books? These questions relate to the propensity for a response to be made at all, and not to the nature of those responses (which we will examine later.) In unreported probit estimates, which are available upon request, the only statistically significant determinant of whether a survey response was completed for a jurisdiction (by either the competition agency or a private sector expert) was whether that jurisdiction had enacted a merger review law or not. Variables corresponding to every other hypothesis mentioned above were statistically insignificant, even at very generous levels of significance. ${ }^{41}$ This finding suggests that whatever faults the 2004 survey might have being unrepresentative of the entire ICN membership is not one of them.

\subsection{Twelve hypotheses concerning the degree of conformity of national merger review regimes with the ICN's Recommended Practices.}

We considered a broad range of hypotheses concerning the degree of conformity drawn from a number of sources; specifically, writings about or by the ICN, writings on competition law and international competition policy, the literature on international relations concerning conformity with voluntary international norms (which are often referred to as "soft law" in that particular literature), and from economics and the study of political economy. We describe each hypothesis in turn.

The first hypothesis concerns the identity of the survey respondent. As noted earlier, the degree of conformity assessed by competition agencies may differ from that assessed by the private sector. Moreover, should the former wish their efforts and particular circumstances to be cast in the best possible light then their responses may indicate greater conformity than that reported by a private sector expert. Recalling also, that in some jurisdictions both a competition agency and a private sector expert answered the survey questionnaires, and given the stated tendency of the survey's organisers to generally defer to the competition agency's assessment when discrepancies arose, then taking all of the above into account, the first hypothesis can be stated thus: the reported degree of conformity will be lower when a private sector expert alone responded to the survey questionnaire.

The second hypothesis is drawn both from the ICN's own publications and from the international relations literature. A sub-group of the ICN's Mergers Working Group noted that its members could contribute to implementation of the ICN's Recommended Practices by "leading by example" (ICN 2005 page 16). Our second hypothesis, then, is that the degree of conformity will be higher for the members of the ICN's Mergers Working Group that drafted the four Recommended Practices which were the subject of the 2004 survey questionnaire. This ICN sub-group also noted that "mature institutions and regional leaders should be aware of their likely influence on newer agencies, and review their own systems accordingly" (ICN 2005b, page 14). If, indeed, more established competition agencies and regional leaders be-

\footnotetext{
${ }^{41}$ Our data on whether a jurisdiction had a merger law in 2004 was taken from ICPAC (2000) (for those jurisdictions that had enacted a merger law up until the publication of the ICPAC report) and was updated to 2004 using the country profiles assembled by the International Bar Association and reported on the website of the Global Competition Forum, www.globalcompetitionforum.org
} 
have in this manner, then membership of the ICN's Mergers Working Group may contribute in a positive and statistically significant manner to conformity. ${ }^{42}$

A "leading by example" dynamic is not the only possible explanation for this second hypothesis, as the literature on international relations makes clear. Goldstein et al (2001) argue that state bodies tend to negotiate and agree to international norms that they intend on following anyway, an implication of which is that the norms agreed by a group of leading countries merely codifies their existing practices. In which case, conformity is more likely to be higher among those jurisdictions whose competition officials drafted these four Recommended Practices.

A third hypothesis concerns the timing of a competition agency's admission to the ICN. In the international relations literature initial members of a group that have agreed certain soft law provisions are said to conform more to these norms, not because they may have drafted those norms, but because they see inherent value in these norms and believe that other official agencies or governments should also adopt them. What matters here, then, is the initial membership of the ICN, rather than the membership of the ICN's Mergers Working Group that drafted the four Recommended Practices in question. (As the latter two groups do not entirely overlap empirical assessment of the second and third hypotheses becomes, in principle, feasible.)

Another logical possibility, which diverges from the third hypothesis, is that competition agencies that joined the ICN after its creation did so in part because they knew they already conformed, by and large, with the Recommended Practices. On this view some competition agencies might fear the international benchmarking that conformity assessments inevitably generate, and not join the ICN in the first place. In which case, latter joiners to the ICN would have degrees of conformity that, on average, were as high or higher than founding members of the ICN.

Yet another possibility is that competition agencies which know their conformity with international norms is weak may join the ICN anyway, so as to signal to other competition agencies (some of whom provide technical assistance or can influence the allocation of technical assistance by others) that they are serious about improving their conformity over time but need help to do so. This argument provides a further rationalisation of the third hypothesis.

The fourth hypothesis arises from the strong presumption in discussions and official publications on competition law and its enforcement of the benefits of establishing independent enforcement agencies. Independence, here, is typically taken to mean the absence of political involvement in the decisions taken by the competition agency. Independent agencies may have greater discretion to conform to the ICN's Recommended Practices, a point that is particularly pertinent given that some of the changes required to meet these Practices need not involve legislation and may well fall within the powers already allocated to a competition agency. The fourth hypothesis, then, is that jurisdictions with independent competition agencies will conform to a greater degree to the ICN's Recommended Practices.

The spread of competition laws around the globe during the last 15 years motivates the fifth hypothesis, namely, that recently established merger review regimes do not conform as much to international norms as more established regimes. A number of rationales for this hypothesis can be advanced. First, the adoption of a merger review regime may be part of the first enactment of a competition law and establishing the competition agency may take priority over adhering to international norms. Second, limited experience with implementing competition law may have not convinced officials of the benefits of transparency and the other norms

\footnotetext{
${ }^{42}$ In this regard readers may wish to note that the obvious candidates for "leadership" and "maturity," the U.S. antitrust agencies and the European Commission, were members of the ICN's Mergers Working Group at the time that the four Recommended Practices in question were drafted.
} 
contained in the ICN's Recommended Practices. Third, jurisdictions with nascent merger review regimes may have smaller communities of private practitioners and academic experts who make the case for adopting international best practices. A contrary perspective is that nascent merger review regimes have the opportunity to adopt international norms from the very beginning.

The sixth hypothesis is motivated by the ICN's own reports of the factors facilitating implementation of the Recommended Practices. ICN (2005b) notes that some competition agencies in jurisdictions in and around Europe remarked that convergence with the European Community Merger Regulation (ECMR) was the key factor in determining whether and how a jurisdiction reformed their merger review regimes. It has even been said that on some occasions the Recommended Practices took second place to the ECMR (see ICN 2005b, page 6). These considerations motivate a sixth hypothesis, namely, that the degree of conformity with the Recommended Practices differs between jurisdictions that (i) are members of the European Union, (ii) are seeking membership of the European Union, or (iii) have an association agreement with the European Union, and other ICN members with merger review regimes. A comparable hypothesis was advanced for those nations with formal cooperation arrangements on antitrust matters with either the United States Government or with the two antitrust enforcement agencies of the United States. To the extent that the European Union's and the U.S.' models of merger review differ in their conformity with the ICN's Recommended Practices, it will be interesting to see if there is any evidence of these agencies influencing the degree of conformity of other agencies that are, for one reason or another, in their respective "orbits."

The seventh legal-cum-institutional hypothesis relates to the legal origins of the jurisdictions that are ICN members. Even though "the [Recommended] Practices are designed to accommodate different legal traditions and stages of development" (ICN 2005b, page 1), it will be useful to examine whether in fact differences in legal tradition appear to influence the degree of conformity reported in the survey used here. Given the leading roles played by the U.S. antitrust authorities and European Commission's competition agency in the ICN, including their role in drafting the Recommended Practices, the seventh hypothesis is that a jurisdiction whose legal system shares a common heritage with that of the U.S. will have a different degree of conformity with the Recommended Practices than other ICN members. A similar hypothesis can be stated for those jurisdictions that share a common legal heritage with the European Union.

The remaining hypotheses concern either purely economic factors or matters relating to the political economy of competition agencies and merger reviews. The eighth hypothesis concerns the potential influence of the size of a nation's economy on conformity. Specifically, we examine whether the degree of conformity with the Recommended Practices is higher in nations with larger economies. There are a number of possible rationales for this hypothesis. For example, larger economies may be politically more powerful and therefore more inclined to act unilaterally. Alternatively, larger economies may wish to act as "benign hegemons" seeking to spread their regulatory values and practices through soft law.

Another factor that might affect the degree of conformity are the resources available to a competition agency. This, in turn, motivates the ninth hypothesis, stated as follows, competition agencies with larger staffs (larger budgets) will exhibit a higher level of conformity with the ICN's Recommended Practices. Higher levels of agency resources may facilitate conformity in so far as the Recommended Practices require staff time and funds to be implemented. In addition, budgetary and personnel resources can facilitate participation in international meetings where Recommended Practices are discussed and in the many telephone conference calls that the ICN Working Groups organise each year.

The value of complying with a set of merger-related international norms may well be higher for those jurisdictions where the value of inward cross-border mergers and acquisitions is 
higher. Agencies may find that the management of their case load is eased by conformity to accepted international norms, providing an incentive to adhere to those norms in the first place. The tenth hypothesis, then, is that conformity is higher in jurisdictions where foreigners are merging with, or acquiring, more domestic firms. An alternative rationale for this hypothesis is that agencies in jurisdictions with plenty of inward cross-border mergers and acquisitions feel greater pressure from other competition agencies and from the private sector bar to comply with international norms.

The eleventh hypothesis is motivated by the domestic political-economy pressures faced by competition agencies, even independent competition agencies (that, after all, may seek to preserve the discretion available to themselves.) This hypothesis states that domestic political pressure influences the degree of conformity to a greater extent in jurisdictions where the excess of the sales of domestic firms to foreigners over sales of foreign firms to own nationals is higher. There are two competing rationales for this hypothesis. First, a nationalistic government could put pressure on its competition agency to reduce the likelihood of foreign acquisitions of domestic corporate assets being approved. The competition agency, perhaps feeling relatively powerless to resist, preserves enough discretion in its merger review regime to act as the government wishes; discretion that may well come at the expense of the agency's conformity with the ICN's Recommended Practices.

An alternative rationale for the eleventh hypothesis is that a forward-looking competition agency seeking to preserve its independence deliberately conforms to international norms so that, should its home government ever seek to encourage it to reduce the number of foreign takeovers of domestic corporations, the agency can argue that de facto discrimination against foreign firms would be relatively obvious to experts at home and abroad. The resulting criticism could, in turn, have significant adverse consequences for the reputation of the national competition enforcement regime and for the perception of the nation's investment climate. This strategy may be more appealing to those competition agencies who are, or expect to be, under significant political pressure to favour domestic firms; if so, then this will induce a positive correlation between the degree of conformity and the likely intensity of political pressure.

The twelfth hypothesis is drawn from the study of international trade flows. A long-standing contention among trade economists (see Bhagwati 1968, Blackhurst 1991) is that open borders can constrain the exercise of market power by firms and in so doing undermine the case for separate state measures against anti-competitive practices, including those that may be created or facilitated by mergers and acquisitions. Jurisdictions with lower barriers to imports may, on this view, feel less need to comply with international norms on merger reviews. An alternative line of argument notes that government agencies in economies that import more goods and services tend to be more aware of the cross-border consequences of corporate transactions and have a greater interest in establishing and abiding by international norms for such transactions. This interest may manifest itself in a number of international fora, one of which is the ICN. Stated neutrally, then, the twelfth hypothesis is that the openness to imports in a jurisdiction influences the degree of conformity with the ICN's Recommended Practices.

The next subsection (5.3) discusses the average level of conformity of the survey respondents with the four Recommended Practices. The subsection that follows (5.4) describes the additional data that was collected so as to enable a statistical evaluation of the twelve hypotheses outlined above. In subsection 5.5 the findings from confronting these 12 hypotheses with the responses to the 2004 survey and the data collected in subsection 5.4 are reported. 


\subsection{A note of caution in interpreting the average level of conformity with the four Recommended Practices.}

After collecting such an enormous amount of information concerning national merger reviews and their conformity with the ICN's Recommended Practices it is perhaps only natural to calculate and report summary statistics on a jurisdiction-by-jurisdiction basis. Taking account of intermediate levels of conformity ${ }^{43}$, Rowley and Campbell (2004) do exactly this, first, by calculating the percentage of times a given jurisdiction was found to be in conformity and, then, ranking jurisdictions on that basis. While this approach has some merits one concern ${ }^{44}$ is that it treats the self-assessments of competition agencies on an equal footing with assessments completed by private sector experts and academics, even though the former may well assess their own conformity more generously than the latter. We explore this matter further here, letting the data reveal any differences in the average propensity to conform across these types of survey respondent or reporter.

The first step we took was to take a firm view of assessments of conformity; that is, only assessments of full conformity counted in an agency's favour and were coded with a survey response of one. Therefore, all other survey responses (including responses indicating partial conformity) were coded as zeros. Next, we created two "reporter" dummy variables; one to indicate where only the competition agency responded to the survey and another to indicate where both the competition agency and a private sector expert responded to the survey. Then, we ran a regression taking the dichotomous survey response as the dependent variable and using the two reporter dummy variables as well as jurisdiction-specific and question-specific fixed effects as independent variables. A probit estimator was used to recover the parameter estimates. These estimates confirm the priors above, namely, that the assessments of competition agencies on their own add positively and statistically significantly to the degree of conformity with the ICN's Recommended Practices. In contrast, survey responses based on the reports of both competition agencies and private sector experts do not report, on average, higher levels of conformity than when the private sector experts reported alone. These parameter estimates where used to forecast what we shall refer to as the unadjusted probability of conformity with each survey question. The mean unadjusted probability of conformity for each jurisdiction was then calculated and the jurisdictions ranked on that basis. The column labelled "Rank" in Table 1 reports the average conformity ranking on this basis and it is very similar to that reported in Rowley and Campbell (2004).

So as to remove the variation created by the reporter's identity, we recalculated for each survey response the probability of conformity had the competition agency alone completed and returned the survey. For each jurisdiction we then calculated the mean of this adjusted probability of conformity and ranked the jurisdictions on this basis. In Table 1 the column labelled "Rank_adj" reports the adjusted ranking produced in this fashion. The neighbouring column labelled "Diff" reveals how adjusting for a common survey respondent affects the ranking of conformity. The case of the United States is particularly instructive. According to Rowley and Campbell (2004, Appendix C) neither of the U.S. antitrust enforcement agencies responded to the survey questionnaire, but a private sector law firm did. The latter's responses, once compared to those made by reporters in other jurisdictions, placed the U.S. at $26^{\text {th }}$ in terms of conformity, just above the half-way mark. Had the only survey respondent from the U.S. been one of its antitrust enforcement agencies we estimate that this factor alone would have propelled it up 18 places to the eighth highest level of conformity, a substantial change. This

\footnotetext{
${ }^{43}$ Recall the responses to some survey questions were coded 0.5 (instead of zero or one) to indicate partial conformity with a particular aspect of the ICN's Recommended Practices.

${ }^{44}$ One cannot, of course, assume that a jurisdiction that conforms with the four Recommended Practices surveyed by the Merger Streamlining Group in 2004 is in conformity with the other Recommended Practices of the International Competition Network. Care must be taken when drawing conclusions from such analyses about the overall level of conformity with all of the ICN's Recommended Practices.
} 
finding is not unique to the United States. Table 1 reveals that, once the reporters identity was controlled for, the rank of 30 of the 56 survey respondent changes by 10 or more places! This latter finding should act as note of caution when interpreting raw scores of conformity with the ICN's Recommended Practices.

\subsection{Other data collected for this study.}

In this subsection we describe the data collected so that each of the 12 hypotheses outlined in subsection 5.2 could be evaluated. We also describe the variables constructed from such data and that were subsequently used in our econometric analysis of the degree of conformity of the ICN membership with four Recommended Practices.

With respect to the first hypothesis, in the last subsection we described how the information contained in the description of the survey (specifically Appendix C of Rowley and Campbell 2004) was used to create two dummy variables relating to the types of survey respondent. We label the dummy variable that refers to those jurisdictions where survey responses were only received from competition agencies as $\mathrm{CA}$. The other dummy variable is referred to as BOTH, corresponding to the case where both the competition agency and a private sector expert submitted survey responses.

With respect to the second and third hypotheses information on the ICN's website ${ }^{45}$ was used to construct a dummy variable to indicate if a jurisdiction was an initial member of the ICN and another dummy variable to indicate if a jurisdiction was a member of the Mergers Working Group that drafted the four Recommended Practices which were the subject of the 2004 survey. These two dummy variables are labelled IM and MWG respectively and both take the value of one if a jurisdiction was involved in the manner described above.

The fourth hypothesis requires some objective means of identifying whether a competition agency is independent or not. This is a particularly difficult matter as independence may not best be thought of as a binary variable. Worse still, there is no widely accepted measure of agency independence. Undeterred, and well aware of the pitfalls and drawbacks, we created a binary independent variable that identified whether a jurisdiction had at least one ${ }^{47}$ competition agency whose office was not located within a government agency or department. The addresses of competition agencies, reported in UNCTAD's 2005 Directory Of Competition Authorities $^{48}$ was used to classify each jurisdiction according to the binary criteria stated above. To the extent that agencies located in ministries are more likely to have their decisions over-ruled by their senior government officials than those located elsewhere, then this method of coding independence has some value. A disadvantage is that physical location of a competition agency is no guarantee of the absence of interference in decision-making from senior government officials. This dummy variable is labelled IA.

Data on whether a jurisdiction has adopted a merger review law in recent years was taken from the national reports posted by the Global Competition Forum at www.globalcompetitionforum.org. A dummy variable was created that took a value of one if a jurisdiction adopted a merger review law for the first time after 31 December 1999. This variable is labelled NML and it will be used to evaluate the fifth hypothesis.

\footnotetext{
${ }^{45}$ www.internationalcompetitionnetwork.org

${ }^{47}$ Some jurisdictions have more than one competition authority at the national level. The United States and Brazil are examples.

${ }^{48}$ This directory can be downloaded from http://www.unctad.org/en/docs//c2clpd49 en.pdf. For the purposes of this study we classified the European Commission's competition agency as independent, a classification which is in line with that agency's perception of its circumstances.
} 
Evaluating the sixth hypothesis requires data on whether a jurisdiction has strong competition-related ties to either the European Union or to the United States. Two dummy variables were created here. The first such variable, labelled ECA, takes a value of one if a jurisdiction was a member of the European Union in 2004, was applying for membership of the European Union in 2004, or had an association agreement with the European Union in that year. The second dummy variable, labelled USA, takes a value of one if the jurisdiction's competition agency was a signatory to a bilateral antitrust cooperation agreement with the United States in 2004. ${ }^{49}$

Information reported in the World Bank's Doing Business database ${ }^{50}$ was used to determine if a jurisdiction's legal system has the same origins or heritage as the European Union or the United States. Again, two dummy variables were created, labelled ECLO and USLO respectively. These two dummy variables took a value of one when a common legal heritage existed and a zero otherwise. This information will be useful for evaluating the seventh hypothesis.

Turning now to the economic and political-economy hypotheses, data on the gross domestic product of each jurisdiction in the sample was collected for the year 2003 from the online version of the World Bank's World Development Indicators. ${ }^{51}$ This data was corrected for differences in purchasing power across jurisdictions. We denote the logarithm of this variable as LGDP and will use the latter as an indicator of the economic size of a jurisdiction.

Data on the staff size and budgets of competition agencies was taken from Nicholson (2001). The budgets were converted into U.S. dollars and the logarithm of them taken, yielding a variable that we shall label LBUDGET. The logarithm of the number of professional staff $f^{52}$ employed by an agency was used to create a variable that we denote LSTAFF. This data was not available for every jurisdiction and traditional techniques were used to impute values of these variables for those jurisdictions where such data was originally missing. ${ }^{53}$

Evaluating hypothesis number ten requires data on inflows of cross-border mergers and acquisitions. The United Nations Conference on Trade and Development's (UNCTAD's) World Investment Report ${ }^{54}$ was the source we used and such flows are reported in millions of US dollars. ${ }^{55}$ For our purposes we took the mean level of cross-border mergers and acquisitions inflows into a jurisdiction for the years 1995 to $2003 .{ }^{56}$ The logarithm of this data was taken and the resulting variable denoted LMA.

The eleventh hypothesis concerned the possible response of a competition agency when foreign purchases of domestic corporate assets exceed domestic purchases of foreign firms creates domestic political pressure on the agency to impede foreign purchases (perhaps by deviating from international best practices on merger review.) This pressure is, by definition, one-

\footnotetext{
${ }^{49}$ A list of these agreements can be found at http://www.usdoj.gov/atr/public/international/int_arrangements.htm

${ }^{50}$ This database can be accessed at http://www.doingbusiness.org/

${ }^{51}$ Subscribers to this database can access it at http://devdata.worldbank.org/dataonline/

${ }^{52}$ Typically trained lawyers, economists, and accountants.

${ }^{53}$ Imputation was done at a prior stage by using the parameter estimates (from a regression of LSTAFF, or where appropriate LBUDGET, on all of the independent variables used in this paper) to forecast the missing values of these resource-related variables.

${ }^{54}$ Information on this report can be found at http://www.unctad.org/Templates/Page.asp?intItemID=1465\&lang=1

${ }^{55}$ It should be noted that UNCTAD does not actually collect this data, instead it makes use of information on cross-border mergers and acquisitions provided by Thompson Financial Securities. As is well know by those who use this data often, even though this data source is probably the best available it is still imperfect and readers should bear this in mind. For a further discussion of this matter see Evenett (2003).

56 Therefore this data precedes the year in which the survey was undertaken, somewhat mitigating concerns about any contemporaneous causation between the characteristics of national merger reviews (surveyed in 2004) and the value of inward cross-border mergers and acquisitions.
} 
sided; that is, the competition agency derives no political credit (or benefit) if on net domestic firms are buying more assets abroad than foreigners are acquiring at home. We construct a comparable cross-jurisdictional variable to proxy for this potential source of political pressure on competition agencies. First, data in the World Investment Report was used to calculate the difference between the value of inward and outward cross-border mergers and acquisitions experienced by a jurisdiction during the years 1995-2003. If that difference is negative, it was set to zero. This difference was divided by the sum of inward and outward cross-border mergers and acquisitions experienced by a jurisdiction, creating an index that lies between zero and one. The number one was then added to each jurisdiction's value of this index and the logarithm of the resulting sum taken, creating a variable we denote as LPOL. ${ }^{58}$ It will be interesting to see whether higher levels of LPOL are associated with a larger or smaller degrees of conformity with the Recommended Practices.

Data on the share of total imports by a jurisdiction in national income, available from the online version of the World Development Indicators, was used to proxy for the openness of a jurisdiction to international trade. The logarithm of one plus this share is denoted LIMP.

Comparing the variables constructed for the legal-cum-institutional factors and the economic and political-economy factors it is apparent that the former are binary in nature whereas the latter are continuous variables. We return to this point when interpreting the econometric results in the next subsection.

\subsection{Econometric approach and estimation results.}

Our goal is to understand which factors correlate with the degree of conformity of the ICN's membership in 2004 with four Recommended Practices on merger review, recognising that these correlates may well differ across classes of ICN members. We would also like to know which, if any, of the 12 hypotheses elaborated earlier tend to be rejected by the data.

The first step was to examine whether the economic and political-economy factors had any explanatory power, having controlled for the variation created by reporter-specific factors (recall the first hypothesis) and question-specific effects. Table 2 reports the marginal effects from a probit regression on a series of economic and political-economy variables (corresponding to hypotheses numbered eight through 12). It is worth noting that in specifications one through six the variables LSTAFF, LBUDGET, and LIMP were purged of the influence of national income (LGDP). This was done to see whether, given their level of national incomes, unusually well-resourced competition agencies or jurisdictions unusually open to trade tended to exhibit different levels of conformity than elsewhere. Specifications seven to nine report the parameter estimates without purging these three variables of national income. Finally, Table 2 is organised so that specifications one, four, and seven (two, five, and eight) [three, six, and nine] were applied to the entire sample of survey responses (the survey responses of the jurisdictions that joined the ICN after it was initially created) [the survey responses of the initial members of the ICN], respectively. A comparison of the correlates of conformity between the initial members and the subsequent members of the ICN is therefore possible.

What findings are there in Table 2? First, the tendency of competition agencies to assess their conformity more highly than private respondents remains a feature of the data; the parameter estimates on CA are always positive and statistically significant. Second, comparing specifications two and three (or five and six, or for that matter, specifications eight and nine), there are clear differences in the determinants of conformity between the initial ICN members and the jurisdictions that subsequently joined the ICN. Third, the size of a jurisdiction's national

\footnotetext{
${ }^{58}$ This transformation is monotonic, so higher values of the original index result in higher values of LPOL.
} 
income (LGDP) correlates positively with conformity only in the sample of initial ICN members. The lack of any such correlation in the sample of subsequent ICN members could be interpreted as implying that the level of development appears not to be an impediment to conformity with these particular Recommended Practices.

Fourth, in both samples conformity was positively correlated with the amount of inward cross-border mergers and acquisitions activity, although the finding here is weaker for those jurisdictions that did not initially join the ICN. Even so, this finding is consistent with the interpretation that competition agencies find conformity to international norms more beneficial when they have to review more transactions with a cross-border component, perhaps because foreign as well as domestic experts are likely to scrutinise these agencies' procedures and decisions.

Fifth, the political-economy variable LPOL works in opposite directions in the two samples of ICN members. Among initial members conformity with the ICN's Recommended Practices tends to be higher in those jurisdictions where foreigners are buying up more domestic corporate assets, suggesting that international norms could be being used to resist domestic political pressure to discriminate in merger reviews. Jurisdictions that joined the ICN after it was formed, however, tend to conform less when foreigners are buying up more domestic corporate assets. For the latter jurisdictions, then, political pressure arising from international corporate restructuring could act as a constraint on the degree to which such jurisdictions can converge to international norms on merger review.

Sixth, the openness of a jurisdiction to trade tends to be positively correlated with conformity with the Recommended Practices in those jurisdictions that subsequently joined the ICN. This finding is hard to square with the argument that open borders make investments in national review regimes unnecessary. Perhaps more interestingly is the fact that such a correlation was not found in the sample of initial ICN members, and this may well account in part for the officials from competition agencies in the founding ICN members seeing no link between openness to trade and adherence to international norms on merger reviews.

Seventh, whether one uses a variable to proxy for the size of the staff of a competition agency or data on its budget, and whether or not one purges those two variables of the variation created by national income, we found that resources do not appear to influence the degree of conformity by initial ICN members. In contrast, resources are positively correlated with conformity for the non-founding ICN members. Many of the latter are developing countries with particularly small budget allocations for their competition agencies and where there are considerable pressing calls on national resources. If this result is robust ${ }^{59}$ then it implies that, for the majority of the ICN's membership, the extent of future convergence in national merger reviews is partly contingent on the resources available to national competition authorities. However, before drawing such a conclusion it is appropriate to examine the effect of the legal-cum-institutional factors on the degree of conformity with the four Recommended Practices. Furthermore, we will be able to check which of the findings from Table 2 are robust to the inclusion of these latter factors.

Table 3 reports the estimation results with the legal-cum-institutional variables for six specifications, two for each of the three samples and with and without the inclusion of the economic and political-economy variables. ${ }^{60}$ The overwhelming impression is that the legalcum-institutional variables poorly correlate with conformity to the four Recommended Practices considered here. Only 11 of the 40 relevant parameter estimates are statistically significant at the 10 percent level. Worse still, when the entire sample of survey responses is

\footnotetext{
${ }^{59} \mathrm{We}$ will discuss a number of robustness checks later in this section.

${ }^{60}$ Since all of the initial members of the ICN had independent competition agencies on our definition, the independent variable IA was dropped from the specification involving sample responses from the initial ICN members.
} 
the 10 percent level. Worse still, when the entire sample of survey responses is split into two samples (for the initial and subsequent ICN members) only four of the 24 estimated parameters for these variables are statistically significant. There is some evidence, however, that being in the orbit of the European Union does raise the level of conformity (the variable ECA being positive and statistically significant in the sample including jurisdictions that subsequently joined the ICN) and arguably this is consistent with the qualitative evidence reported in one of the ICN's own documents (ICN 2005b). Although the overall performance of the legal and institutional variables is very poor, we would remind readers that this may be due to the rather blunt (in this case, binary) proxies used to capture cross-jurisdictional differences in these variables. Should more fine-grained proxies become available then it would be worth revisiting this particular econometric analysis.

How did the inclusion of the legal-cum-institutional variables in the regressions affect the estimated parameters for the economic and political-economy variables? The level of development (proxied by LGDP) ceases to be positively correlated with the degree of conformity of the initial ICN members. Agency resources (LSTAFF) still constrains the conformity of the many jurisdictions that joined the ICN after it was formed. The volume of inward mergers and acquisitions (LMA) is still positively correlated with conformity in both samples. The proxies for political pressure (LPOL) still influences the degree of conformity in differing ways (raising conformity by the initial ICN members and lowering it among the later joiners). Openness to trade (LIMP) ceases to be a determinant of conformity among subsequent joiners, just as it was among the initial members of the ICN. Overall, then, three of the five findings from Table 2 carry over to Table 3, that is, they are not undermined by the inclusion of the legal and institutional variables in the econometric specifications.

Next we performed a series of robustness checks. The first check was to control for the receipt of merger-related technical assistance by a jurisdiction. As ICN (2005b) notes some of those ICN members which supply technical assistance to other competition agencies have incorporated information about the ICN's work into their assistance programmes. One hypothesis, therefore, is that to the extent that recipients implement the ICN-related advice, their degree of conformity will be higher than those who do not receive such technical assistance. Another hypothesis is that the receipt of technical assistance is influenced by the perceived degree of conformity with the ICN's recommendations, creating a potential endogenity problem. In a similar vein, those countries that receive technical assistance may have certain common attributes, such as having lower levels of national income or having recently enacted a merger review law. In what follows we will try to sort out some of these effects.

Our first step in this regard was to collect data on the number of merger-related technical assistance programmes that each ICN member received during 2000-2003. Many suppliers of technical assistance report such information to the Organisation for Economic Co-operation and Development and the World Trade Organization, which has been assembled into a joint database $^{61}$ on technical assistance and capacity building activities on a wide range of government policies. This database was the source used while conducting this particular robustness check. We cannot rule out the possibility that some technical assistance programmes were not reported to the OECD and the WTO. For each jurisdiction we created a dummy variable, denoted LTA, which took the value of one if a jurisdiction received at least one merger-related technical assistance programme during 2000-2003. Taking the samples of survey responses of the initial ICN members and other members separately, our second step was to run probit regressions using question-specific effects, reporter-specific effects (CA and BOTH), the economic and political-economy variables (used in Table 2) and the variable LTA as independent variables. ${ }^{62}$ The estimation results for these two samples are reported in the first two columns

\footnotetext{
${ }^{61}$ This database can be accessed at http://tcbdb.wto.org/

${ }^{62}$ Note, therefore, that we drop the under-performing legal-cum-institutional variables.
} 
of Table 4. The previous qualitative findings are unchanged by the inclusion of the technical assistance term. The latter is found to be negatively correlated with conformity suggesting, amongst other explanations, that assistance is targeted towards under-conforming jurisdictions.

Our third step was to correct for the endogenity of the technical assistance term by creating an instrument for LTA that is a function of the following variables: whether a jurisdiction was formerly a communist country (plenty of technical assistance has been directed towards the transition economies since the fall of the Berlin Wall), the national income per capita of the jurisdiction (data on which was obtained from the online version of the World Development Indicators), and whether the jurisdiction shared a colonial link with Britain, France, Spain, or the United States (generating two dummy variables, one for the European nations and one for the United States.) This instrument was then used in an Instrumental Variables (IV) probit estimation procedure to recover the marginal effects reported in the third and fourth columns of Table $4{ }^{63}$ There are two qualitative implications of this approach. One is that the level of development is no longer positively correlated with conformity in the sample of initial ICN members, otherwise the signs and significance of the other independent variables are unchanged. The other implication is that the effect of technical assistance on conformity has diminished in the sample of newer ICN members, suggesting that selection effects were indeed important. Overall, though, the broad thrust of the findings that arose from the estimates reported in Tables 2 and 3, especially as they relate to the economic and political-economy variables, remains intact after controlling for the receipt of technical assistance.

In a second set of robustness checks partial conformity was now coded the same way as full conformity. That is, instead of coding survey responses given values of 0.5 as zero we now assign them values of one. We ran the principal specifications again with this alternative dependent variable and the results are reported in Table 5. In specifications seven through nine, where all of the independent variables are included, a small number of changes result. The level of national income ceases to be positively correlated with conformity by initial members, but openness to trade becomes significant at the ten percent level for that sample. Interestingly, resources cease to be a constraint on the level of conformity of jurisdictions that joined the ICN later. ${ }^{64}$ The findings concerning the volume of cross-border mergers and acquisitions and political pressure remain robust to the change in dependent variable.

Turning to the performance of the legal-cum-institutional variables in Table 5, a more generous evaluation of partial conformity generates one change. That is, jurisdictions whose legal system has the same origins or heritage as those of the European Community are found to have lower levels of conformity. For jurisdictions that are also in the orbit of the European Union this effect is offset by close economic ties with Europe (the marginal effect on the EULO term is smaller in absolute value than that for the ECA parameter). In short, though, modifying the dependent variable does not rescue the legal and institutional variables from their general tendency towards statistical insignificance.

In principle, one could examine whether the correlates of conformity differ across each of the four Recommended Practices. Recovering parameter estimates for the newer and initial members separately for each of the four Recommended Practices would involve undertaking probit estimations on much smaller samples, with the likely result that few, if any, estimated parameters would be statistically significant. Instead of taking the latter approach, we dropped in turn the survey responses from each of the four Recommended Practices, recovered four

\footnotetext{
${ }^{63}$ Specifically, we used the Amemiya Generalised Least Squares (AGLS) estimator which was designed to deal with endogenous regressors in probit models, see Newey (1987) for details. In the STATA statistical package this amounts to using the divprob procedure.

${ }^{64}$ The point can still be made, however, that resources available to competition agencies appear to be a constraint on full conformity with the Recommended Practices.
} 
new sets of parameter estimates, and examined how robust the previous findings are to these changes in sample composition. For the survey responses from non-founding ICN members this approach results in sample sizes that good practice suggests are large enough, however for the initial ICN members this approach often leaves us with only 150 data points or so to estimate over forty parameters. In fact, we found considerable parameter instability in the latter case; whether this is due to sample composition or too few degrees of freedom is hard to say.

For the new ICN members excluding the survey responses on review periods, requirements for initial notification, and review of merger control provisions has no discernable effects on the parameter estimates. ${ }^{65}$ Dropping the survey responses on transparency, however, undermines the explanatory power of previously significant economic and political-economy variables, leaving only one legal variable and the reporting dummy variable CA statistically significant. We interpret this findings as follows: the degree of conformity of jurisdictions to international norms on transparency is affected by economic and political-economy factors, which is important to know as the transparency of national regulatory regimes are the subject of discussions in a number of international fora. For the other three international norms, however, once question-specific and reporter-specific variation is taken account of, changes in economic, political-economy, legal, and institutional factors neither constrain nor facilitate conformity with these norms. ${ }^{66}$

Another potential econometric concern arises because of potential non-zero correlations between the residuals from the same jurisdiction, a concern that may be particularly relevant given that our independent variables are jurisdiction-specific. We employed Moulton's technique to "cluster" errors around jurisdictions, estimating the principal specifications accordingly (Moulton 1990). In estimation results that are available upon request we find that, with the exception of the openness variable, the economic and political-economy variables retain the same signs and significance at standard levels. Clustering does not alter the broad patterns of insignificant results for the legal and institutional factors.

What, in conclusion, are we to make of this barrage of statistical estimates? In our view it would be churlish to infer that "law and institutions" do not matter. Regression tools are well suited to examining the independent contribution of individual influences on endogenous variables, and here we have found that pulling any one legal or institutional lever does not seem to lead to greater conformity. This finding does not exclude the logical possibility that the adoption of packages of legal and institutional measures can result in improvements in the conformity with international norms on merger reviews. In contrast, resources and political pressures on competition agencies do appear to independently influence the degree of conformity with international norms on merger review, in particular those norms that relate to transparency of national merger reviews.

\section{Concluding remarks.}

In this paper we have reviewed the state-of-the-art knowledge on the economic effects of cross-border mergers and acquisitions and undertaken, what we believe to be, the first econometric analysis of a leading international policy initiative concerning merger review regimes. Juxtaposing these two matters was revealing; the review of the economic literature pointed to the inefficiencies and potential for resource misallocation created by uncoordinated national merger reviews, while a leading initiative on mergers (that is, the International Com-

\footnotetext{
${ }^{65}$ These parameter estimates are available from the authors upon request.

${ }^{66}$ Separately, one might also question whether it is appropriate to include the European Commission and the competition agencies of the EU member states in the same sample. Despite the loss of observations, the findings remain qualitatively unchanged if one excludes the survey responses from the member states of the EU.
} 
petition Network) seeks to foster the adoption of best practices in national merger reviews. This creates a potential mismatch between theory and practice as it is not apparent how the adoption of best practices and inter-agency cooperation will eliminate the potential for the resource misallocation caused by the independent implementation of merger reviews. The desire to preserve independence in competition law enforcement may well account for this state of affairs, but a failure to demonstrate empirically that uncoordinated multi-jurisdictional merger reviews creates substantial resource misallocation is another possible explanation. Future economic research may well remedy this deficiency, even so the reluctance to pool sovereignty is likely to be very strong.

The econometric analysis in this paper may be significant for three reasons. First, it highlights the likely role that resources and political-economy factors play in affecting the degree to which jurisdictions adhere to internationally-accepted best practices in merger reviews. Beyond the founding members of the ICN the limited resources devoted to competition agencies and the apparent pressure to resist foreign takeovers of domestic corporate assets were found to constrain the degree of conformity with four of the ICN's Recommended Practices on merger reviews. This finding must surely cast doubt on whether this non-binding international initiative will eventually result in widespread convergence in national merger regimes. This conclusion should be qualified, however, by the fact that our analysis only considers a subset of the ICN's Recommended Practices.

The second reason is that this paper is one of the few econometric evaluations of conformity with non-binding international agreements, which international relations and legal scholars often refer to as "soft law". These scholars tend to overlook economic factors as determinants of conformity with soft law, yet we find some of these factors to be correlated with conformity to international norms on merger reviews. Having said that, the differences between the founding and later ICN members in the factors influencing the degree of conformity, that were revealed by the econometric analysis in this paper, are consistent with some of the hypotheses advanced by international relations scholars. Our principal observation here is that there is a case for broadening the set of hypotheses concerning the degree of conformity with soft law.

The empirical analysis in this paper is relevant to the debate within international trade circles (and elsewhere) on the relative merits of binding versus non-binding international obligations. The former have come in for particular criticism in recent years because they are thought to place too much resource-related burdens on signatories, in particular on developing countries. Concerns about so-called implementation costs have led some to advocate treating some regulatory matters, such as competition law and policy, in non-binding agreements. This latter policy recommendation would be undermined somewhat if it were found that the degree of participation or the benefits of participating in non-binding international initiatives were also constrained either by the availability of resources or by political-economy pressures. Our empirical analysis shows that these constraints are indeed at work in the merger area ${ }^{67}$; a finding which points to the need for a more balanced discussion of the pros and cons of different types of international obligation on competition law and policy.

There is plenty of scope for future research into the determinants of conformity with soft law obligations on competition law-related matters. Our analysis examined conformity at a point in time but, should another survey of these four Recommended Practices be conducted, then this would allow for an analysis of the changes in conformity over time. Here one could explore the extent to which any political-economy and resource-based constraints on conformity are being overcome, or reinforced, over time. Such analyses might also shed light on the con-

\footnotetext{
${ }^{67}$ We note, however, that showing that resource availability constrains conformity with soft law does not speak to the matter of the relative magnitude of the resource costs associated with potential soft and hard international accords.
} 
tributions that technical assistance and cooperation arrangements between competition agencies are making to improve conformity over time. Researchers might also profitably examine the compliance with other prominent non-binding initiatives on competition law and policy, such as the OECD's Recommendations on Hard Core Cartels and on Merger Review.

Further examination on the linkages between compliance with international accords, decisionmaking by competition agencies, and resource allocation would strengthen our understanding of the implications, both positive and adverse, of multi-jurisdictional merger reviews. One goal of such research might be to better understand the ways in which international initiatives on competition law and enforcement are altering how firms restructure their operations in a globalising world economy, in particular whether they seek to merge with or acquire other firms or whether they adjust in other ways. 


\section{References.}

Barros, P.P. and L. Cabral (1994). "Merger policy in open economies", European Economic Review, Vol. 38, pp. 1041-1055.

Bhagwati (1968). Bhagwati, Jagdish N. The Theory and Practice of Commercial Policy. International Finance Section, Dept. of Economics. Princeton, N.J.: Princeton University.

Bjorvatn, K. (2004). "Economic integration and the profitability of cross-border mergers and acquisitions", European Economic Review, forthcoming.

Blackhurst (1991). Blackhurst, Richard. "Trade Policy is Competition Policy." Paper prepared for the OECD. Paris, France.

Bode and Budzinksi (2005). Bode, Mariana, and Oliver Budzinski. "Competing Ways Towards International Antitrust: the WTO versus the ICN." Forthcoming in Frank Columbus (ed.) New Developments in Antitrust, New York: Nova.

Budzinksi (2004). Budzinski, Oliver. "The International Competition Network. Prospects and Limits on the Road towards International Competition Governance." Paper prepared for a research project titled International Competition Policy--Towards a Decentralised System of International Merger Control. February 13.

Cabral, L. (2005). "An Equilibrium Approach to International Merger Policy”, forthcoming in International Journal of Industrial Organization.

Dixit, A. (1984). "International Trade Policy for Oligopolistic Industries", Economic Journal, Vol. 94, pp. 1-16.

Evenett, S.J. (2003). "The Cross Border Mergers and Acquisitions Wave of the Late 1990s", in R.E. Baldwin and L.A. Winters (eds), Challenges to Globalization, University of Chicago Press for the NBER.

Falvey, R. (1998). "Mergers in Open Economies", The World Economy, Vol. 21, pp. 10611076.

Farrell, J. and C. Shapiro (1990). "Horizontal mergers: An Equilibrium analysis", American Economic Review, Vol. 80, No.1, pp. 107-126.

Ferrett, B. (2005). "Greenfield Investment versus Acquisition: Alternative Modes of Foreign Expansion”, GEP Research Paper, 2005/39.

Goldstein et. al. (2001). Goldstein, Judith L., Miles Kahler, Robert O. Keohane, and AnneMarie Slaughter (eds.) Legalization and World Politics. MIT Press. Cambridge, MA.

Horn, H. and J. Levinsohn (2001). "Merger Policies and Trade Liberalisation", Economic Journal, Vol. 111, No. 470, pp. 244-276.

Horn, H. and L. Persson (2001a). "Endogenous Mergers in Concentrated Markets", International Journal of Industrial Organization, Vo. 19, pp. 1213-1244.

Horn, H. and L. Persson (2001b). "The Equilibrium Ownership of an International Oligopoly”, Journal of International Economics, Vol. 53, pp. 307-333.

ICN (2005a). International Competition Network. A Statement Of Mission And Achievements Up Until May-2005. Available at www.internationalcompetitionnetwork.org

ICN (2005b). International Competition Network. Implementation Of The ICN Recommended Practices For Merger Notification and Review Procedures. Notifications and Procedures Subgroup of the ICN's Mergers Working Group. April. Available at http://www.internationalcompetitionnetwork.org/bonn/Mergers_WG/SG1_Notification_Procedures/Implementation.pdf 
ICPAC (2000). International Competition Policy Advisory Committee To The Attorney General And Assistant Attorney General For Antitrust. Final Report. U.S. Government Printing Office.

Jenny (2003). Jenny, Frédéric. "International cooperation on competition: myth, reality and perspective." The Antitrust Bulletin. Winter 2003, 973-1003.

Kraus and Coppola (2004). Kraus, Elizabeth F., and Maria B. Coppola. "The International Competition Network: A Virtual Reality." Bureau of Competition, U.S. Federal Trade Commission.

Levinsohn, J. (1993). "Testing the Imports-as-Market-Discipline Hypothesis", Journal of International Economics, Vol. 35, pp. 1-22.

Lommerud, K.E., O.R. Straume and L. Sørgard (2005). "National versus international mergers in unionised oligopoly", RAND Journal of Economics.

Moulton, B. R (1990). "An Illustration of a Pitfall in Estimating the Effects of Aggregate Variables on Micro Unit", The Review of Economics and Statistics, Vol.2(2), pp. 334-38.

Muris (2001). Muris, Timothy J. "Merger Enforcement in a World of Multiple Arbiters." Prepared remarks before the Brookings Institution's Roundtable on Trade and Investment Policy. 21 December 2001.

Neary, J. P. (2004). "Cross-border mergers as instruments of comparative advantage", University College Dublin, mimeo.

Neven, D.J. and L. Röller (2000a). "The Allocation of Jurisdiction in International Antitrust", European Economic Review, vol. 44, no. 4-6, pp. 845-55.

Neven, D.J. and L. Röller (2000b). "Consumer Surplus vs. Welfare Standard in a Political Economy Model of Merger Control”, WZB Discussion Paper, 00/15.

Neven, D.J. and P. Seabright (1997). "Trade Liberalisation and the Coordination of Competition Policy", in L. Waverman, W. Comanor and A. Goto (eds.), Competition Policy in the Global Economy, Modalities for Cooperation, London: Routledge.

Newey, W. (1987). "Simultaneous estimation of limited dependent variable models with endogenous explanatory variables", Journal of Econometrics, Vol. 36, No. 3, pp. 231-250.

Nicholson (2004). Nicholson, Michael W. "Quantifying Antitrust Regimes." Bureau of Economics, U.S. Federal Trade Commission. Working paper number 267. February.

Norback, P.-J. and L. Persson (2004). "Privatization and Foreign Competition", Journal of International Economics, Vol. 62, pp. 409-416.

Salant, S, S. Switzer and R. Reynolds (1983). "Losses from Horizontal Merger: The Effect of an Exogenous Change in Industry Structure on Cournot-Nash Equilibrium", Quarterly Journal of Economics, Vol. 98, 185-199.

Rowley and Campbell (2004). Rowley, J. William, and A. Neil Campbell. "Implementation Of The International Competition Network's Recommended Practices (IV-VII) For Merger Notification Procedures. Preliminary Report on a Survey Commissioned by The Merger Streamlining Group." April.

Rowley and Campbell (2005). Rowley, J. William, and A. Neil Campbell. "Implementation of the ICN's Recommended Merger Practices: A Work-in-(Early)-Progress." The Antitrust Source. July 2005 online edition available at www.antitrustsource.com

Ryan (2005). Ryan, Stephen. "Some Thoughts on Co-operation Between Competition Agencies." Powerpoint presentation to a conference titled "Competition Policy Foundations For 
Trade Reform, Regulatory Reform And Sustainable Development", 19-20 October 2005. Paris.

Saggi, K and H.M. Yildiz (2006). "On the International Linkage Between Trade and Merger Policies", Review of International Economics, forthcoming.

Tay, A. and G. Willman (2005). "Why (no) Global Competition Policy is a Tough Choice", Quarterly Review of Economics and Finance, Vol. 45 (2-3), pp. 312-324.

UNCTAD (2000). United Nations Conference on Trade and Development. World Investment Report 2000: Cross-border Mergers and Acquisitions and Development. Geneva.

UNCTAD (2002). United Nations Conference on Trade and Development. World Investment Report 2002: Transnational Corporations and Export Competitiveness. Geneva. 
Figure 1: Decentralised versus Centralised Merger Review

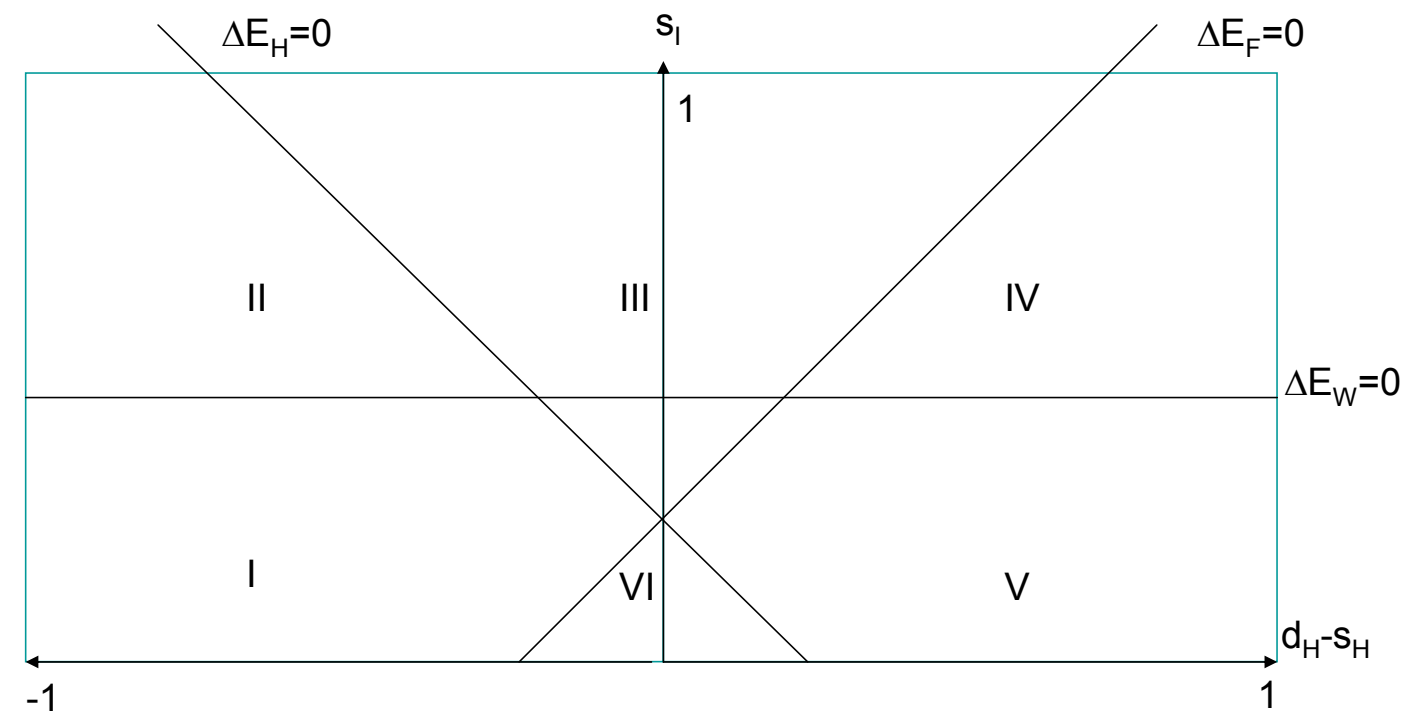


Table 1. Reporter-adjusted rankings of conformity.

\begin{tabular}{lccclccc}
\hline Country & Rank & Rank_adj & Diff & Country & Rank & Rank_adj & Diff \\
\hline Argentina & 42 & 27 & 15 & Kyrgyzstan & 51 & 46 & 5 \\
Armenia & 41 & 45 & -4 & Latvia & 27 & 28 & -1 \\
Australia & 7 & 4 & 3 & Lithuania & 6 & 19 & -13 \\
Austria & 32 & 48 & -16 & Macedonia & 39 & 20 & 19 \\
Azerbaijan & 48 & 42 & 6 & Malta & 9 & 6 & 3 \\
Belgium & 34 & 51 & -17 & Mexico & 1 & 2 & -1 \\
Brazil & 44 & 36 & 8 & New Zealand & 19 & 34 & -15 \\
Bulgaria & 28 & 47 & -19 & Norway & 12 & 24 & -12 \\
Canada & 15 & 30 & -15 & Peru & 50 & 44 & 6 \\
Croatia & 46 & 38 & 8 & Philippines & 53 & 49 & 4 \\
Cyprus & 33 & 33 & 0 & Poland & 36 & 52 & -16 \\
Czech Republic & 13 & 7 & 6 & Portugal & 25 & 25 & 0 \\
Denmark & 29 & 9 & 20 & Romania & 20 & 35 & -15 \\
Estonia & 14 & 26 & -12 & Russia & 43 & 29 & 14 \\
European Union & 4 & 17 & -13 & Slovak Republic & 21 & 15 & 6 \\
Finland & 10 & 22 & -12 & South Africa & 16 & 31 & -15 \\
Germany & 2 & 13 & -11 & Spain & 35 & 12 & 23 \\
Greece & 23 & 39 & -16 & Switzerland & 18 & 14 & 4 \\
Hungary & 17 & 32 & -15 & Taiwan & 8 & 5 & 3 \\
Iceland & 40 & 23 & 17 & Thailand & 55 & 53 & 2 \\
India & 30 & 10 & 20 & Tunisia & 49 & 43 & 6 \\
Indonesia & na & na & na & Turkey & 37 & 18 & 19 \\
Israel & 31 & 11 & 20 & Ukraine & 38 & 54 & -16 \\
Italy & 24 & 40 & -16 & United Kingdom & 3 & 16 & -13 \\
Japan & 22 & 21 & 1 & United States & 26 & 8 & 18 \\
Kazakhstan & 47 & 41 & 6 & Uzbekistan & 45 & 37 & 8 \\
Kenya & 54 & 50 & 4 & Venezuela & 52 & 55 & -3 \\
Korea & 11 & 1 & 10 & Zambia & 5 & 3 & 2 \\
\hline \hline
\end{tabular}


Table 2. The marginal effects of economic and political-economy factors on the degree of conformity with four ICN Recommended Practices.

\begin{tabular}{|c|c|c|c|c|c|c|c|c|c|}
\hline \multirow{2}{*}{$\begin{array}{l}\text { Independ- } \\
\text { ent variable } \\
\text { (relevant } \\
\text { hypothesis } \\
\text { number) } \\
\end{array}$} & \multicolumn{9}{|c|}{ Specification number } \\
\hline & 1 & 2 & 3 & 4 & 5 & 6 & 7 & 8 & 9 \\
\hline CA (1) & $\begin{array}{c}0.326 \\
(0.037) \\
* * *\end{array}$ & $\begin{array}{c}0.301 \\
(0.044) \\
* * *\end{array}$ & $\begin{array}{c}0.546 \\
(0.119) \\
* * *\end{array}$ & $\begin{array}{c}0.306 \\
(0.038) \\
* * *\end{array}$ & $\begin{array}{c}0.287 \\
(0.045) \\
* * *\end{array}$ & $\begin{array}{c}0.525 \\
(0.130) \\
* * *\end{array}$ & $\begin{array}{c}0.326 \\
(0.037) \\
* * *\end{array}$ & $\begin{array}{c}0.300 \\
(0.044) \\
* * *\end{array}$ & $\begin{array}{c}0.541 \\
(0.120) \\
* * *\end{array}$ \\
\hline BOTH (1) & $\begin{array}{l}-0.059 \\
(0.042)\end{array}$ & $\begin{array}{l}-0.003 \\
(0.050)\end{array}$ & $\begin{array}{l}-0.042 \\
(0.096)\end{array}$ & $\begin{array}{l}-0.037 \\
(0.042)\end{array}$ & $\begin{array}{c}0.019 \\
(0.049)\end{array}$ & $\begin{array}{l}-0.070 \\
(0.093)\end{array}$ & $\begin{array}{l}-0.061 \\
(0.042)\end{array}$ & $\begin{array}{c}-0.003 \\
(0.049)\end{array}$ & $\begin{array}{l}-0.052 \\
(0.097)\end{array}$ \\
\hline LGDP (8) & $\begin{array}{c}0.009 \\
(0.011)\end{array}$ & $\begin{array}{l}-0.006 \\
(0.015)\end{array}$ & $\begin{array}{c}0.044 \\
(0.018) \\
* *\end{array}$ & $\begin{array}{c}0.025 \\
(0.010) \\
* * *\end{array}$ & $\begin{array}{c}0.016 \\
(0.014)\end{array}$ & $\begin{array}{c}0.044 \\
(0.024) \\
*\end{array}$ & $\begin{array}{c}0.075 \\
(0.014) \\
* * *\end{array}$ & $\begin{array}{c}0.062 \\
(0.018) \\
* * *\end{array}$ & $\begin{array}{c}0.079 \\
(0.040) \\
* *\end{array}$ \\
\hline $\begin{array}{l}\text { LPOL } \\
\text { (11) }\end{array}$ & $\begin{array}{c}-0.319 \\
(0.090) \\
* * *\end{array}$ & $\begin{array}{c}-0.387 \\
(0.107) \\
* * *\end{array}$ & $\begin{array}{c}0.932 \\
(0.267) \\
* * *\end{array}$ & $\begin{array}{c}-0.276 \\
(0.082) \\
* * *\end{array}$ & $\begin{array}{c}-0.323 \\
(0.096) \\
* * *\end{array}$ & $\begin{array}{c}0.928 \\
(0.270) \\
* * *\end{array}$ & $\begin{array}{c}-0.323 \\
(0.089) \\
* * *\end{array}$ & $\begin{array}{c}-0.392 \\
(0.105) \\
* * *\end{array}$ & $\begin{array}{c}0.925 \\
(0.266) \\
* * *\end{array}$ \\
\hline LIMP (12) & $\begin{array}{c}0.112 \\
(0.042) \\
* * *\end{array}$ & $\begin{array}{c}0.122 \\
(0.050) \\
* *\end{array}$ & $\begin{array}{c}0.119 \\
(0.100)\end{array}$ & $\begin{array}{c}0.125 \\
(0.042) \\
* * *\end{array}$ & $\begin{array}{c}0.132 \\
(0.051) \\
* * *\end{array}$ & $\begin{array}{c}0.098 \\
(0.104)\end{array}$ & $\begin{array}{c}0.112 \\
(0.041) \\
* * *\end{array}$ & $\begin{array}{c}0.123 \\
(0.050) \\
* *\end{array}$ & $\begin{array}{c}0.117 \\
(0.100)\end{array}$ \\
\hline LMA (10) & $\begin{array}{c}0.027 \\
(0.009) \\
* * *\end{array}$ & $\begin{array}{c}0.028 \\
(0.010) \\
* * *\end{array}$ & $\begin{array}{c}0.063 \\
(0.034) \\
*\end{array}$ & $\begin{array}{c}-0.005 \\
(0.008)\end{array}$ & $\begin{array}{l}-0.004 \\
(0.008)\end{array}$ & $\begin{array}{c}0.079 \\
(0.035) \\
* *\end{array}$ & $\begin{array}{c}0.028 \\
(0.009) \\
* * *\end{array}$ & $\begin{array}{c}0.029 \\
(0.010) \\
* * *\end{array}$ & $\begin{array}{c}0.067 \\
(0.034) \\
* *\end{array}$ \\
\hline $\begin{array}{l}\text { LSTAFF } \\
\text { (9) }\end{array}$ & 0.085 & 0.086 & 0.042 & & & & 0.087 & 0.087 & 0.028 \\
\hline & $\begin{array}{c}(0.022) \\
* * *\end{array}$ & $\begin{array}{c}(0.026) \\
* * *\end{array}$ & $(0.053)$ & & & & $\begin{array}{c}(0.021) \\
* * *\end{array}$ & $\begin{array}{c}(0.025) \\
* * *\end{array}$ & $(0.053)$ \\
\hline $\begin{array}{l}\text { LBUDGET } \\
\text { (9) }\end{array}$ & & & & $\begin{array}{c}0.058 \\
(0.014) \\
* * *\end{array}$ & $\begin{array}{c}0.052 \\
(0.016) \\
* * *\end{array}$ & $\begin{array}{l}-0.010 \\
(0.050)\end{array}$ & & & \\
\hline Sample & Full & $\begin{array}{l}\text { Non- } \\
\text { found- } \\
\text { ing ICN } \\
\text { mem- } \\
\text { bers }\end{array}$ & $\begin{array}{c}\text { Found- } \\
\text { ing ICN } \\
\text { mem- } \\
\text { bers }\end{array}$ & Full & $\begin{array}{l}\text { Non- } \\
\text { found- } \\
\text { ing ICN } \\
\text { mem- } \\
\text { bers }\end{array}$ & $\begin{array}{c}\text { Found- } \\
\text { ing ICN } \\
\text { mem- } \\
\text { bers }\end{array}$ & Full & $\begin{array}{l}\text { Non- } \\
\text { found- } \\
\text { ing ICN } \\
\text { mem- } \\
\text { bers }\end{array}$ & $\begin{array}{l}\text { Found- } \\
\text { ing ICN } \\
\text { mem- } \\
\text { bers }\end{array}$ \\
\hline $\begin{array}{l}\text { Number } \\
\text { observa- } \\
\text { tions }\end{array}$ & 1279 & 977 & 261 & 1279 & 977 & 261 & 1279 & 977 & 261 \\
\hline $\begin{array}{l}\text { Pseudo R- } \\
\text { squared }\end{array}$ & 0.21 & 0.21 & 0.24 & 0.22 & 0.22 & 0.23 & 0.21 & 0.22 & 0.23 \\
\hline $\begin{array}{l}\text { Log Like- } \\
\text { lihood }\end{array}$ & -672.84 & -528.04 & -103.78 & -670.06 & -527.11 & -104.04 & -672.2 & -527.59 & -103.93 \\
\hline
\end{tabular}

Notes: Reported coefficients are the marginal effects of the variable in question. Robust standard errors are reported in parentheses. * denotes statistical significance at the $10 \%$ level; ** denotes statistical significance at the $5 \%$ level; $* * *$ denotes statistical significance at the $1 \%$ level. All specifications include question-specific fixed effects. In specifications 1-6 the variables LSTAFF, LBUDGET, and LIMP are purged of the influence of national income, LGDP. 
Table 3. The marginal effects of legal-cum-institutional, economic, and politicaleconomy variables on the degree of conformity with four ICN Recommended Practices.

\begin{tabular}{|c|c|c|c|c|c|c|}
\hline \multirow{2}{*}{$\begin{array}{l}\text { Independent variable } \\
\text { (relevant hypothesis } \\
\text { number) }\end{array}$} & \multicolumn{6}{|c|}{ Specification number } \\
\hline & 1 & 2 & 3 & 4 & 5 & 6 \\
\hline $\mathrm{CA}(1)$ & $\begin{array}{c}0.291 \\
(0.039) \\
* * *\end{array}$ & $\begin{array}{c}0.276 \\
(0.047) \\
* * *\end{array}$ & $\begin{array}{c}0.253 \\
(0.098) \\
* * *\end{array}$ & $\begin{array}{c}0.285 \\
(0.041) \\
* * *\end{array}$ & $\begin{array}{c}0.266 \\
(0.048) \\
* * *\end{array}$ & $\begin{array}{c}0.408 \\
(0.222) \\
*\end{array}$ \\
\hline BOTH (1) & $\begin{array}{c}-0.010 \\
(0.043)\end{array}$ & $\begin{array}{c}0.052 \\
(0.052)\end{array}$ & $\begin{array}{c}-0.043 \\
(0.081)\end{array}$ & $\begin{array}{c}-0.054 \\
(0.046)\end{array}$ & $\begin{array}{c}0.009 \\
(0.056)\end{array}$ & $\begin{array}{c}-0.002 \\
(0.181)\end{array}$ \\
\hline LGDP (8) & & & & $\begin{array}{c}-0.008 \\
(0.014)\end{array}$ & $\begin{array}{c}0.002 \\
(0.019)\end{array}$ & $\begin{array}{c}0.054 \\
(0.065)\end{array}$ \\
\hline LPOL (11) & & & & $\begin{array}{c}-0.232 \\
(0.102) \\
* *\end{array}$ & $\begin{array}{c}-0.274 \\
(0.132) \\
* *\end{array}$ & $\begin{array}{c}0.886 \\
(0.539) \\
*\end{array}$ \\
\hline LIMP (12) & & & & $\begin{array}{c}0.067 \\
(0.051)\end{array}$ & $\begin{array}{c}0.025 \\
(0.071)\end{array}$ & $\begin{array}{c}0.020 \\
(0.128)\end{array}$ \\
\hline LMA (10) & & & & $\begin{array}{c}0.021 \\
(0.009) \\
* *\end{array}$ & $\begin{array}{c}0.02 \\
(0.011) \\
*\end{array}$ & $\begin{array}{c}0.159 \\
(0.074) \\
* *\end{array}$ \\
\hline LSTAFF (9) & & & & $\begin{array}{c}0.038 \\
(0.027)\end{array}$ & $\begin{array}{c}0.051 \\
(0.031) \\
*\end{array}$ & $\begin{array}{c}0.012 \\
(0.083)\end{array}$ \\
\hline IA (4) & $\begin{array}{c}0.064 \\
(0.038) \\
*\end{array}$ & $\begin{array}{c}0.056 \\
(0.041)\end{array}$ & & $\begin{array}{c}0.057 \\
(0.047)\end{array}$ & $\begin{array}{c}0.041 \\
(0.056)\end{array}$ & \\
\hline MWG (2) & $\begin{array}{c}0.057 \\
(0.057)\end{array}$ & $\begin{array}{c}0.185 \\
(0.077) \\
* *\end{array}$ & $\begin{array}{c}-0.059 \\
(0.056)\end{array}$ & $\begin{array}{c}-0.009 \\
(0.071)\end{array}$ & $\begin{array}{c}0.068 \\
(0.107)\end{array}$ & $\begin{array}{c}-0.022 \\
(0.084)\end{array}$ \\
\hline ECA (6) & $\begin{array}{c}0.096 \\
(0.035) \\
* * *\end{array}$ & $\begin{array}{c}0.139 \\
(0.041) \\
* * *\end{array}$ & $\begin{array}{c}0.015 \\
(0.067)\end{array}$ & $\begin{array}{c}0.061 \\
(0.042)\end{array}$ & $\begin{array}{c}0.128 \\
(0.055) \\
* *\end{array}$ & $\begin{array}{l}-0.135 \\
(0.147)\end{array}$ \\
\hline USA (6) & $\begin{array}{c}0.026 \\
(0.061)\end{array}$ & $\begin{array}{c}0.113 \\
(0.120)\end{array}$ & $\begin{array}{c}-0.021 \\
(0.050)\end{array}$ & $\begin{array}{c}0.009 \\
(0.064)\end{array}$ & $\begin{array}{c}0.095 \\
(0.134)\end{array}$ & $\begin{array}{l}-0.026 \\
(0.069)\end{array}$ \\
\hline NML (5) & $\begin{array}{c}-0.092 \\
(0.051) \\
*\end{array}$ & $\begin{array}{c}-0.056 \\
(0.053)\end{array}$ & - & $\begin{array}{c}-0.108 \\
(0.056) \\
*\end{array}$ & $\begin{array}{c}-0.050 \\
(0.064)\end{array}$ & - \\
\hline EULO (7) & $\begin{array}{c}-0.066 \\
(0.037) \\
*\end{array}$ & $\begin{array}{c}-0.081 \\
(0.042) \\
*\end{array}$ & $\begin{array}{c}-0.064 \\
(0.084)\end{array}$ & $\begin{array}{c}-0.047 \\
(0.041)\end{array}$ & $\begin{array}{c}-0.082 \\
(0.053)\end{array}$ & $\begin{array}{l}-0.057 \\
(0.104)\end{array}$ \\
\hline USLO (7) & $\begin{array}{l}-0.003 \\
(0.045)\end{array}$ & $\begin{array}{c}0.042 \\
(0.055)\end{array}$ & $\begin{array}{c}-0.094 \\
(0.063)\end{array}$ & $\begin{array}{c}-0.03 \\
(0.048)\end{array}$ & $\begin{array}{c}0.019 \\
(0.057)\end{array}$ & $\begin{array}{l}-0.163 \\
(0.182)\end{array}$ \\
\hline IM (3) & $\begin{array}{c}0.176 \\
(0.061) \\
* * *\end{array}$ & & & $\begin{array}{c}0.191 \\
(0.062) \\
* * *\end{array}$ & & \\
\hline Observations & 1279 & 977 & 261 & 1279 & 977 & 261 \\
\hline Pseudo R-squared & 0.22 & 0.22 & 0.17 & 0.23 & 0.22 & 0.25 \\
\hline Log Likelihood & -662.45 & -527.37 & -113.06 & -657.61 & -522.08 & -101.38 \\
\hline
\end{tabular}

Notes: Reported coefficients are the marginal effects of the variable in question. Robust standard errors are reported in parentheses. * denotes statistical significance at the $10 \%$ level; ** denotes statistical significance at the $5 \%$ level; *** denotes statistical significance at the $1 \%$ level. All specifications include question-specific fixed effects. 
Table 4. Controlling for the receipt of technical assistance: A robustness check.

\begin{tabular}{|c|c|c|c|c|}
\hline \multirow{3}{*}{$\begin{array}{l}\text { Independent variable } \\
\text { (relevant hypothesis } \\
\text { number) } \\
\text { CA (1) }\end{array}$} & \multicolumn{4}{|c|}{ Specification number and estimation technique } \\
\hline & 1 & 2 & 3 & 4 \\
\hline & $\begin{array}{c}0.286 \\
(0.044) \\
* * *\end{array}$ & $\begin{array}{c}0.554 \\
(0.134) \\
* * *\end{array}$ & $\begin{array}{c}0.297 \\
(0.049) \\
* * *\end{array}$ & $\begin{array}{c}0.534 \\
(0.129) \\
* * *\end{array}$ \\
\hline BOTH (1) & $\begin{array}{c}0.017 \\
(0.051)\end{array}$ & $\begin{array}{l}-0.064 \\
(0.111)\end{array}$ & $\begin{array}{c}0.000 \\
(0.056)\end{array}$ & $\begin{array}{l}-0.071 \\
(0.115)\end{array}$ \\
\hline LGDP (8) & $\begin{array}{l}-0.005 \\
(0.016)\end{array}$ & $\begin{array}{c}0.05 \\
(0.020) \\
* *\end{array}$ & $\begin{array}{l}-0.005 \\
(0.016)\end{array}$ & $\begin{array}{c}0.050 \\
(0.020)\end{array}$ \\
\hline LPOL (11) & $\begin{array}{c}-0.240 \\
(0.116) \\
* *\end{array}$ & $\begin{array}{c}0.967 \\
(0.264) \\
* * *\end{array}$ & $\begin{array}{c}-0.336 \\
(0.174) \\
*\end{array}$ & $\begin{array}{c}0.941 \\
(0.272) \\
* * *\end{array}$ \\
\hline LIMP (12) & $\begin{array}{c}0.104 \\
(0.050) \\
* *\end{array}$ & $\begin{array}{l}0.130 \\
(0.105)\end{array}$ & $\begin{array}{c}0.116 \\
(0.050) \\
* *\end{array}$ & $\begin{array}{c}0.112 \\
(0.105)\end{array}$ \\
\hline LMA (10) & $\begin{array}{c}0.031 \\
(0.010) \\
* * *\end{array}$ & $\begin{array}{c}0.067 \\
(0.033) \\
* *\end{array}$ & $\begin{array}{c}0.029 \\
(0.011) \\
* * *\end{array}$ & $\begin{array}{c}0.068 \\
(0.039) \\
* *\end{array}$ \\
\hline LSTAFF (9) & $\begin{array}{c}0.099 \\
(0.027) \\
* * *\end{array}$ & $\begin{array}{c}0.034 \\
(0.053)\end{array}$ & $\begin{array}{c}0.088 \\
(0.030) \\
* * *\end{array}$ & $\begin{array}{c}0.029 \\
(0.058)\end{array}$ \\
\hline LTA & $\begin{array}{c}-0.129 \\
(0.047) \\
* * *\end{array}$ & $\begin{array}{c}0.067 \\
(0.067)\end{array}$ & $\begin{array}{c}-0.038 \\
(0.124) \\
* *\end{array}$ & $\begin{array}{c}0.066 \\
(0.063)\end{array}$ \\
\hline $\begin{array}{l}\text { Number of } \\
\text { observations }\end{array}$ & 977 & 261 & 977 & 261 \\
\hline Pseudo R-squared & 0.22 & 0.24 & 0.22 & 0.24 \\
\hline Log Likelihood & -524.83 & -103.33 & -528.00 & -103.27 \\
\hline
\end{tabular}

Notes: Reported coefficients are the marginal effects of the variable in question. Robust standard errors are reported in parentheses. $*$ denotes statistical significance at the $10 \%$ level; $* *$ denotes statistical significance at the $5 \%$ level; *** denotes statistical significance at the $1 \%$ level. All specifications include question-specific fixed effects. 
Table 5. Alternative dependent variables: Another robustness check.

\begin{tabular}{|c|c|c|c|c|c|c|c|c|c|}
\hline \multirow{2}{*}{$\begin{array}{l}\text { Independent } \\
\text { variable (hypothesis) }\end{array}$} & \multicolumn{9}{|c|}{ Specification number } \\
\hline & 1 & 2 & 3 & 4 & 5 & 6 & 7 & 8 & 9 \\
\hline CA (1) & $\begin{array}{c}0.283 \\
(0.037) \\
* * *\end{array}$ & $\begin{array}{c}0.288 \\
(0.044) \\
* * *\end{array}$ & $\begin{array}{c}0.614 \\
(0.130) \\
* * *\end{array}$ & $\begin{array}{c}0.258 \\
(0.037) \\
* * *\end{array}$ & $\begin{array}{c}0.271 \\
(0.046) \\
* * *\end{array}$ & $\begin{array}{c}0.218 \\
(0.104) \\
* *\end{array}$ & $\begin{array}{c}0.244 \\
(0.039) \\
* * *\end{array}$ & $\begin{array}{c}0.251 \\
(0.047) \\
* * *\end{array}$ & $\begin{array}{c}0.557 \\
(0.226) \\
* *\end{array}$ \\
\hline BOTH (1) & $\begin{array}{l}-0.061 \\
(0.039)\end{array}$ & $\begin{array}{l}-0.003 \\
(0.047)\end{array}$ & $\begin{array}{l}-0.066 \\
(0.095)\end{array}$ & $\begin{array}{l}-0.047 \\
(0.040)\end{array}$ & $\begin{array}{c}0.006 \\
(0.049)\end{array}$ & $\begin{array}{l}-0.079 \\
(0.081)\end{array}$ & $\begin{array}{c}-0.07 \\
(0.042) \\
*\end{array}$ & $\begin{array}{l}-0.008 \\
(0.054)\end{array}$ & $\begin{array}{l}-0.032 \\
(0.161)\end{array}$ \\
\hline LGDP (8) & $\begin{array}{c}0.012 \\
(0.010)\end{array}$ & $\begin{array}{c}0.004 \\
(0.014)\end{array}$ & $\begin{array}{c}0.041 \\
(0.015) \\
* * *\end{array}$ & & & & $\begin{array}{l}-0.003 \\
(0.012)\end{array}$ & $\begin{array}{c}0.006 \\
(0.018)\end{array}$ & $\begin{array}{c}0.073 \\
(0.049)\end{array}$ \\
\hline LPOL (11) & $\begin{array}{c}-0.224 \\
(0.078) \\
* * *\end{array}$ & $\begin{array}{c}-0.301 \\
(0.097) \\
* * *\end{array}$ & $\begin{array}{c}0.97 \\
(0.265) \\
* * *\end{array}$ & & & & $\begin{array}{c}-0.18 \\
(0.087) \\
* *\end{array}$ & $\begin{array}{c}-0.219 \\
(0.123) \\
*\end{array}$ & $\begin{array}{c}1.075 \\
(0.446) \\
* *\end{array}$ \\
\hline LIMP (12) & $\begin{array}{c}0.039 \\
(0.035)\end{array}$ & $\begin{array}{c}0.021 \\
(0.045)\end{array}$ & $\begin{array}{c}0.159 \\
(0.106)\end{array}$ & & & & $\begin{array}{l}-0.026 \\
(0.042)\end{array}$ & $\begin{array}{l}-0.102 \\
(0.064)\end{array}$ & $\begin{array}{c}0.151 \\
(0.083) \\
*\end{array}$ \\
\hline LMA (10) & $\begin{array}{c}0.019 \\
(0.007) \\
* * *\end{array}$ & $\begin{array}{c}0.021 \\
(0.009) \\
* *\end{array}$ & $\begin{array}{c}0.028 \\
(0.030)\end{array}$ & & & & $\begin{array}{c}0.019 \\
(0.008) \\
* *\end{array}$ & $\begin{array}{c}0.019 \\
(0.010) \\
* *\end{array}$ & $\begin{array}{c}0.111 \\
(0.063) \\
*\end{array}$ \\
\hline LSTAFF (9) & $\begin{array}{c}0.051 \\
(0.019) \\
* * *\end{array}$ & $\begin{array}{c}0.051 \\
(0.023) \\
* *\end{array}$ & $\begin{array}{c}0.059 \\
(0.047)\end{array}$ & & & & $\begin{array}{c}0.024 \\
(0.023)\end{array}$ & $\begin{array}{c}0.033 \\
(0.028)\end{array}$ & $\begin{array}{l}-0.055 \\
(0.084)\end{array}$ \\
\hline MWG (2) & & & & $\begin{array}{c}0.034 \\
(0.046)\end{array}$ & $\begin{array}{c}0.125 \\
(0.060) \\
* *\end{array}$ & $\begin{array}{l}-0.041 \\
(0.054)\end{array}$ & $\begin{array}{l}-0.026 \\
(0.062)\end{array}$ & $\begin{array}{c}0.044 \\
(0.091)\end{array}$ & $\begin{array}{c}0.046 \\
(0.082)\end{array}$ \\
\hline $\mathrm{ECA}(6)$ & & & & $\begin{array}{c}0.08 \\
(0.030) \\
* * *\end{array}$ & $\begin{array}{c}0.119 \\
(0.038) \\
* * *\end{array}$ & $\begin{array}{c}0.016 \\
(0.062)\end{array}$ & $\begin{array}{c}0.081 \\
(0.036) \\
* *\end{array}$ & $\begin{array}{c}0.162 \\
(0.051) \\
* * *\end{array}$ & $\begin{array}{l}-0.164 \\
(0.119)\end{array}$ \\
\hline USA (6) & & & & $\begin{array}{c}0.057 \\
(0.050)\end{array}$ & $\begin{array}{c}0.138 \\
(0.082) \\
*\end{array}$ & $\begin{array}{l}-0.004 \\
(0.048)\end{array}$ & $\begin{array}{c}0.037 \\
(0.053)\end{array}$ & $\begin{array}{c}0.072 \\
(0.110)\end{array}$ & $\begin{array}{l}-0.034 \\
(0.054)\end{array}$ \\
\hline EULO (7) & & & & $\begin{array}{c}-0.062 \\
(0.033) \\
*\end{array}$ & $\begin{array}{l}-0.062 \\
(0.039)\end{array}$ & $\begin{array}{c}-0.187 \\
(0.110) \\
*\end{array}$ & $\begin{array}{c}-0.078 \\
(0.038) \\
* *\end{array}$ & $\begin{array}{c}-0.109 \\
(0.052) \\
* *\end{array}$ & $\begin{array}{l}-0.258 \\
(0.167)\end{array}$ \\
\hline USLO (7) & & & & $\begin{array}{l}-0.038 \\
(0.040)\end{array}$ & $\begin{array}{l}-0.006 \\
(0.051)\end{array}$ & $\begin{array}{c}-0.151 \\
(0.064) \\
* *\end{array}$ & $\begin{array}{c}-0.082 \\
(0.045) \\
*\end{array}$ & $\begin{array}{l}-0.057 \\
(0.056)\end{array}$ & $\begin{array}{l}-0.126 \\
(0.143)\end{array}$ \\
\hline IA (4) & & & & $\begin{array}{c}0.023 \\
(0.032)\end{array}$ & $\begin{array}{c}0.018 \\
(0.037)\end{array}$ & & $\begin{array}{c}0.01 \\
(0.039)\end{array}$ & $\begin{array}{l}-0.017 \\
(0.051)\end{array}$ & \\
\hline NML (5) & & & & $\begin{array}{c}-0.099 \\
(0.049) \\
* *\end{array}$ & $\begin{array}{l}-0.073 \\
(0.053)\end{array}$ & & $\begin{array}{c}-0.112 \\
(0.054) \\
* *\end{array}$ & $\begin{array}{l}-0.064 \\
(0.065)\end{array}$ & \\
\hline IM (3) & & & & $\begin{array}{c}0.132 \\
(0.048) \\
* * *\end{array}$ & & & $\begin{array}{c}0.145 \\
(0.048) \\
* * *\end{array}$ & & \\
\hline Observations & 1224 & 935 & 209 & 1224 & 935 & 209 & 1224 & 935 & 209 \\
\hline $\begin{array}{l}\text { Pseudo } \\
\text { R-squared }\end{array}$ & 0.24 & 0.25 & 0.26 & 0.25 & 0.25 & 0.17 & 0.26 & 0.27 & 0.3 \\
\hline $\begin{array}{l}\text { Log } \\
\text { Likelihood }\end{array}$ & -555.48 & -447.24 & -70.8 & -547.18 & -447.25 & -79.26 & -541.56 & -438.64 & -67.06 \\
\hline
\end{tabular}

Notes: Reported coefficients are the marginal effects of the variable in question. Robust standard errors are reported in parentheses. $*$ denotes statistical significance at the $10 \%$ level; $* *$ denotes statistical significance at the $5 \%$ level; *** denotes statistical significance at the $1 \%$ level. All specifications include question-specific fixed effects. 